\title{
Kollektive forhandlinger for oppdragstakere?
}

Rekkevidden av adgangen til å forhandle tariffavtaler i lys av internasjonal rettsutvikling

Nye tilknytningsformer, blant annet i den digitale plattformøkonomien, aktualiserer spørsmålet om visse oppdragstakere skal kunne forhandle tariffavtaler. Adgangen til å forhandle tariffavtaler i norsk rett er ikke skarpt avgrenset, og det er heller ikke et rent nasjonalrettslig spørsmål. Adgangen må fastlegges i lys av konkurranserettslige skranker og menneskerettsbeskyttelsen av retten til kollektive forhandlinger. Artikkelen drøfter utviklingen av relevante internasjonale regler og viser at de i større grad enn før åpner for - og taler for - en adgang til å forhandle tariffavtaler for visse oppdragstakere. Forfatteren peker på at fleksibiliteten i arbeidstakerbegrepet kan benyttes i en utvidende tolkning som omfatter gråsonetilfellene. Det argumenteres for at det vil være i tråd med arbeidstvistlovens formål, avhjelpe avgrensningsproblemer, effektivisere forhandlingsretten og derfor kunne være en hensiktsmessig tilpasning til utviklingen på arbeidsmarkedet.

MARIANNE JENUM HOTVEDT, cand. jur. 2002 og ph.d. 2015 (UiO); førsteamanuensis ved Institutt for privatrett, Det juridiske fakultet (UiO) og leder for Arbeidsrettsgruppen samme sted.

NØKKELORD: kollektive forhandlinger, tariffunntak, organisasjonsfrihet, oppdragstaker, arbeidstaker

\section{$1 \quad$ En prinsipiell og aktuell problemstilling ${ }^{1}$}

Temaet for denne artikkelen er kollektive forhandlinger om arbeidsvilkår for oppdragstakere. Problemstillingen er mer presist om visse oppdragstakere skal kunne forhandle tariffavtaler innenfor arbeidstvistlovgivningens rammeverk. ${ }^{2}$ Siktemålet er ikke å gi nøyaktige svar på hvem som omfattes av dette rammeverket, men å klarlegge tolkningsmulighetene i lys av internasjonal rettsutvikling. ${ }^{3}$

1 En stor takk til Alexander Næss Skjønberg og øvrige deltakere i Arfa-alumniet, Stein Evju samt Arbeidsretts anonyme fagfelle for verdifulle innspill til artikkelen. Gjenstående svakheter er naturligvis mitt ansvar.

2 Lov 27. januar 2012 nr. 9 om arbeidstvister (arbeidstvistloven, atvl.) og lov 18. juli $1958 \mathrm{nr} .2 \mathrm{om}$ tjenestetvister (tjenestetvistloven, tjtvl.), se også lov 27. januar 2012 nr. 10 om lønnsnemnd i arbeidstvister (lønnsnemndsloven). Arbeidstvistloven er i $§ 1$ bokstav a positivt avgrenset mot tjenestetvistloven, som gjelder for arbeidstakere ansatt i statens tjeneste, jf. tjtvl. § 1 (1). Drøftelsen i det følgende tar utgangspunkt i arbeidstvistloven.

3 Et fokus på mulighetene er betimelig blant annet fordi Arbeids- og sosialdepartementet 23. august 2019 nedsatte et «Utvalg for fremtidens arbeidsliv», med mandat til å «vurdere grenseoppgangene mellom ulike 
Noen vil straks undre seg over at problemstillingen overhodet reises. Arbeidstvistloven er uttrykkelig innrettet for organisasjoner for arbeidstakere og forhandlinger om vilkår i arbeidsavtaler. Adgang til kollektive forhandlinger er imidlertid ikke et rent nasjonalrettslig anliggende. Organisasjonsfriheten innebærer en rett til kollektive forhandlinger, og en ny avgjørelse viser at retten ikke nødvendigvis er avgrenset til arbeidstakere. I saken ICTU vs. Irland $^{4}$ fra september 2018 ble det lagt grunn at visse oppdragstakere skal ha rett til å forhandle kollektivt etter Den reviderte europeiske sosialpakt (ESP) art. 6 nr. 2. ${ }^{5}$ Avgjørelsen har vakt oppmerksomhet og reist debatt internasjonalt. Et sentralt spørsmål er hvordan menneskerettsbeskyttelsen kan og skal avstemmes mot EU/EØS-rettens konkurranseregler, som setter skranker for kollektiv opptreden, men som også anerkjenner et såkalt «tariffunntak». I en avgjørelse fra 2014 - FNV Kunsten - åpnet EU-domstolen for at visse oppdragstakere sidestilles med arbeidstakere og faller inn under tariffunntaket. ${ }^{6}$

Rettsutviklingen aktualiserer spørsmålet om i hvilken grad internasjonale regler nå åpner for og eventuelt krever - at nasjonal rett gir oppdragstakere adgang til kollektive forhandlinger. ${ }^{7}$

Denne diskusjonen bør også bringes inn i norsk rett, og den kan knyttes til tolkningen av arbeidstvistloven. Lovens avgrensning av adgangen til å forhandle tariffavtaler er ikke skarp, særlig fordi arbeidstakerbegrepet er fleksibelt. Arbeidstakerbegrepet avgrenses etter en helhetsvurdering av realitetene. ${ }^{8}$ Man kan derfor tenkes å være arbeidstaker i

tilknytningsformer, og om begrepene, herunder arbeidstakerbegrepet, er tydelige og hensiktsmessige og omfatter de grupper det er ønskelig at de skal omfatte», se nærmere

https://www.regjeringen.no/no/dep/asd/om-arbeids--og-sosialdepartementet/nemnder-styrer-rad-ogutvalg/midlertidige-nemnder-rad-og-utvalg/fremtidens-arbeidsliv/id2666296/. Utvalget skal levere sin utredning innen 21. juni 2021.

Avgjørelse fra European Committee of Social Rights (Sosialpaktkomiteen) 12. september 2018 i Irish Congress of Trade Unions (ICTU) v. Irland, klage nr. 123/2016. I resolusjon fra Europarådets ministerkomité 12. desember 2018, CM/ResChS(2018)11, er avgjørelsen tatt til etterretning. Idet det ikke ble konstatert noen aktuell krenkelse, ble det ikke anbefalt noen bestemt oppfølgning fra Irlands side.

Den opprinnelige sosialpakten er fra 1961, mens Den reviderte sosialpakten - European Social Charter (revised), European Treaty Series 163 - er fra 1996, i kraft 1. juli 1999. Sistnevnte ble ratifisert av Norge 7. mai 2001, men enkelte andre stater er fremdeles er bundet av den opprinnelige. I det følgende brukes ESP som kortform for den reviderte. Den sentrale bestemmelsen for drøftelsen videre - art. $6 \mathrm{nr}$. 2 - er uansett identisk i de to konvensjonene.

6 Dom 4. desember 2014, FNV Kunsten Informatie en Media, C-413/13, EU:C:2014:2411.

7 Hvorvidt oppdragstakere skal/kan/bør ha adgang til kollektive forhandlinger, er tatt opp av flere i senere år, se blant annet Mark Freedland and Nicola Kountouris, «Some Reflections on the 'Personal Scope' of Collective Labour Law», Industrial Law Journal Vol. 46 (2017) s. 52-71, https://doi.org/10.1093/indlaw/dww041, Marco Biasi, «’We will all laugh at guilded butterflies'. The shadow of antitrust law on the collective negotiations of fair fees for self-employed workers», European Labour Law Journal Vol. 9 (2018) s. 354-373, https://doi.org/10.2139/ssrn.3159161, Michael Doherty og Valentina Franca, «Solving the 'Gig-saw': Collective Rights and Platform Work», Industrial Law Journal (publisert elektronisk 25. desember 2019), https://doi.org/10.1093/indlaw/dwz026, og Valerio De Stefano og Antonio Aloisi, «Fundamental Labour Rights, Platform Work and Human-Rights Protection of NonStandard Workers» i Janice R. Bellace og Beryl ter Haare (red.), Research Handbook on Labour, Business and Human Rights Law 2019 s. 359-379.

Se nærmere i punkt 3. For øvrig er både prinsippet om «primacy of the facts» og behovet for en helhetlig vurdering anerkjent $\mathrm{i}$ en rekke nasjonale systemer. For en komparativ oversikt, se Bernd Waas og Guus 
arbeidstvistlovens forstand selv om man formelt fremstår som en oppdragstaker, ved å arbeide etter kontrakt(er) betegnet som oppdragskontakter og/eller være regnet som selvstendig etter andre regler.

Innenfor rammen av arbeidstvistloven er kategoriene dikotomier; en person er enten arbeidstaker eller oppdragstaker i denne lovens forstand. Men i virkeligheten befinner arbeidsrelasjonene seg på en glideskala. I ytterpunktene finner vi dem som opplagt er enten arbeidstaker eller oppdragstaker, både formelt og reelt. Mellom ytterpunktene finner vi personer som formelt fremstår som oppdragstakere, men der realitetene i større eller mindre grad har likhetstrekk med arbeidstakerforhold. Dersom realiteten er et tydelig over- og underordningsforhold, med plikt til å stå til rådighet samt ledelse og kontroll fra arbeidsgiver, er det klart at personen er arbeidstaker. Da er det tale om en omgåelse, såkalt «sham selfemployment». På midten av skalaen gjenstår det likevel en gråsone: Personer som formelt fremstår som selvstendige, samtidig som det er usikkert og diskutabelt om realitetene tilsier at de er arbeidstakere eller oppdragstakere. Usikkerheten er særlig uttalt der det ikke er et tydelig underordningsforhold, men relasjonen preges av sosioøkonomiske maktskjevheter, noe som kan anses som en form for $\emptyset$ konomisk avhengighet. Som artikkelen vil vise, kan usikkerhet $\mathrm{i}$ denne gråsonen åpne for en utvidende forståelse av hvem som skal ha adgang til å forhandle tariffavtaler.

En kjent tilnærming i møtet med dette gråsoneproblemet er å utvide rekkevidden for visse arbeidsrettslige regler. Flere nasjonale systemer adresserer problemet ved lovfestede utvidelser, der bestemte regler - for eksempel adgangen til kollektiv regulering av arbeidsvilkår - omfatter visse oppdragstakere. Utvidelsene omfatter gjerne oppdragstakere som av ulike grunner kan betegnes som økonomisk avhengige. ${ }^{9}$ Også i norsk rett gir visse arbeidsrettslige regler et vern av oppdragstakere. ${ }^{10}$

Utviklingen i arbeidsmarkedet aktualiserer spørsmålet om adgang til kollektive forhandlinger for flere enn tradisjonelle arbeidstakere. ${ }^{11}$ Det er lenge sett en tendens til kontraktsformer som utfordrer skillet mellom arbeidstakere og oppdragstakere og derved skaper usikkerhet om virkeområdet for sentrale arbeidsrettslige regler. ${ }^{12}$ Formidlings- eller

Heerma van Voss (red.), Restatement of Labour Law in Europe. Volume 1 The Concept of Employee, 2017 [Waas/van Voss 2017], https://doi.org/10.5040/9781509912438.

9 Se eksempler fra italiensk lovgivning nedenfor i note 23 og fra britisk lovgivning i note 24, samt et eksempel fra nederlandsk lovgivning i punkt 4.2. Svensk rett gir et annet eksempel. Etter lag (1976:580) om medbestämmande i arbetslivet $1 \S 2$ stycket er «den som utför arbete åt annan och därvid ej är anställd hos denne men har en ställning av väsentligen samma slag som en anställd», sidestilt med en arbeidstaker. Det er også eksempler fra land som Irland, Tyskland, Spania og Canada, se om det irske eksemplet i punkt 5.3.2.

Se nærmere Marianne Jenum Hotvedt, Arbeidsgiverbegrepet, 2016 [Hotvedt 2016] særlig s. 209-216 og s. 255-258.

Til illustrasjon er alle teoribidragene som er nevnt i note 7 knyttet opp mot utviklingen av plattformøkonomien.

12

Det har blant annet vakt bekymring i ILO og EU. I ILO dannet det bakgrunnen for en egen rekommandasjon, The Employment Relationship Recommendation nr. 198 fra 2006. I EU dannet det 
plattformøkonomien har gitt vekst - og potensial for ytterligere vekst - i gråsonen. Det er kommet nye forretningsmodeller kjennetegnet ved at en digital plattform kobler personer som utfører arbeid, direkte med sluttkundene. ${ }^{13}$ Arbeidspersonen behandles vanligvis som en selvstendig oppdragstaker, og plattformen bygger derfor på at arbeidsrettslige regler ikke får anvendelse. ${ }^{14}$ Rettsavgjørelser fra andre land viser at slike modeller kan være rene omgåelser. ${ }^{15}$ Men det er viktig å erkjenne at de gjerne ligger i gråsonen. Arbeidspersonen vil ofte ha adskillig større frihet enn en vanlig arbeidstaker til å velge tid, sted og omfang av arbeid, og plattformen er sjelden direkte involvert i hvordan arbeidet utføres. Samtidig kan plattformen ha en markedsposisjon der den i praksis dikterer vilkårene, også ut mot sluttkundene. Det kan forsterke skjeve forhandlingsposisjoner og gjøre den enkelte $\varnothing$ konomisk avhengig av plattformen. Et flertall i Delingsøkonomiutvalget har tatt til orde for at slike sosioøkonomiske maktskjevheter $b \phi r$ gi adgang til å forhandle kollektivt. Flertallet poengterte at maktforholdet mellom plattform og enkeltstående tjenestetilbydere «er i utgangspunktet skjevt», og mente at oppdragstakere som ikke selv fastsetter priser direkte overfor kunder, bør kunne forhandle kollektive avtaler med plattformdrivere selv om de ikke anses som arbeidstakere. ${ }^{16}$ OECD har nylig anbefalt styrkede rettigheter for oppdragstakere i gråsonen mer generelt, blant annet når det gjelder tilgang til kollektive forhandlinger, for å møte utfordringene i dagens og fremtidens arbeidsliv. ${ }^{17}$

Problemstillingens praktiske aktualitet kan illustreres ved hjelp av plattformene Foodora og Deliveroo. Begge opererer internasjonalt med app-baserte løsninger for å bringe mat fra

bakgrunnen for en egen studie, Adalberto Perulli, Economically Dependent/Quasi-subordinate (Parasubordinate) Employment. Legal, Social and Economic Aspects, Study for the EU Commission, 2003. Det er også bakgrunnen for et nylig vedtatt direktiv, direktiv 2019/1152/EU om tydelige og forutsigbare arbeidsvilkår, som avløser direktiv 91/533/EØF om informasjon om arbeidsvilkårene. Det nye direktivet er hjemlet i Treaty of the Functioning of the European Union (TFEU) art. 153, som ikke er omfattet av EØSavtalen. Det er foreløpig ikke avklart om direktivet vil anses EØS-relevant [XX oppdateres i korrekturen].

Internasjonalt betegnes dette blant annet som «platform work», «gig-work», «crowdwork» og «app-based work». Se nærmere Valerio De Stefano, «The rise of the 'just-in-time workforce': In-demand work, crowdwork and labor protection in the 'gig-economy'», Comparative Labor Law \& Policy Journal, Vol. 37 (2016), s. 471-503, https://doi.org/10.2139/ssrn.2682602. Her trekkes det et skille mellom «crowdwork» (arbeid utført på digitale plattformer) og «work-on-demand via app» (stedsbundet arbeid tilbudt gjennom digitale plattformer).

I Norge er det imidlertid enkelte plattformer som velger arbeidsavtaler som tilknytningsform, se Kristin Jesnes, «Employment Models of Platform Companies in Norway : A Distinctive Approach?», Nordic Journal of Working Life Studies, Vol. 9 (2019) s. 53-73, https://doi.org/10.18291/njwls.v9is6.114691.

Et kjent eksempel er prosessen mot Uber i London, se dom 19. desember 2018 fra England and Wales Court of Appeal (Civil Division) Decision i sak nr. A2/2017/3467 Uber BV and other companies v. Y. Aslam, J. Farrar and others, [2018] WCA Civ 2748. I den forutgående avgjørelsen fra Employment Tribunal (case No: 2202550/2015) er det uttalt at ideen om at hver sjåfør driver en selvstendig virksomhet, er «faintly ridiculous». For en kommentar, se Jemma Thomas, «Court of Appeal rejects Uber's worker status appeal», European Employment Law Cases, No. 22019 s. 112-114, https://doi.org/10.5553/eelc/187791072019004002014. Prosessen er ikke avsluttet; Uber har fått tillatelse fra Court of Appeal til anke til Supreme Court. 
restauranter til kunder, primært ved hjelp av sykkelbud. I Norge anerkjenner Foodora at sykkelbudene er arbeidstakere. ${ }^{18}$ Budene er organisert i Fellesforbundet og har - etter en streik - oppnådd tariffavtale med høyere lønn og bedrede arbeidsvilkår. ${ }^{19}$ Bud som benytter moped eller bil, regnes imidlertid som oppdragstakere. ${ }^{20}$ Ellers i Europa har Foodora foreløpig holdt fast ved at budene er oppdragstakere, og det er ingen andre kjente eksempler på at selskapet har innlatt seg på tarifforhandlinger. ${ }^{21}$ I Torino i Italia ble fem bud tvert imot oppsagt fordi de forsøkte å mobilisere for bedre betaling i et chatrom. I rettsprosessene som fulgte, ble de regnet som oppdragstakere. ${ }^{22}$ En særskilt utvidelse for $\emptyset$ konomisk avhengige oppdragstakere ga likevel rett til tilsvarende lønn som arbeidstakere. ${ }^{23}$ Deliveroo opererer ikke i Norge, men er en stor aktør blant annet i London. Også der har budene organisert seg, krevet tariffavtale og aksjonert for å sette makt bak kravet. Etter to runder i rettsapparatet er status at budene etter det relevante britiske regelverket ikke er «workers», men oppdragstakere, og avskåret fra å forhandle tariffavtale etter britisk rett. I ankeomgangen anførte budene forgjeves at dette var i strid med retten til kollektive forhandlinger etter Den europeiske menneskerettskonvensjon (EMK) art. $11 .^{24}$

Videre i artikkelen presenterer jeg først utgangspunktene og problemstillingene noe nærmere (punkt 2). Jeg drøfter så rekkevidden av arbeidstvistlovgivningens rammeverk og viser hvilke avgrensningsproblemer som reiser seg (punkt 3). Deretter diskuteres

Det kan ha sammenheng med at Arbeidstilsynet gjennomførte tilsyn med virksomheten og traff vedtak om pålegg 19. juli 2016, ref. 2016/20783, som bygget på at budene var arbeidstakere.

Se pressemelding fra Foodora, «Foodora inngår moderne tariffavtale etter nye forhandlinger», www.foodora.no/contents/foodora-inngår-moderne-tariffavtale, 27. september 2019.

På Foodoras nettside fremgår det at personer som vil arbeide som moped- eller bilbud i Norge må opprette enkeltmannsforetak, se https://rider.foodora.no/.

21 Alf Tore Bergsli, «Kan digitale arbeidere drømme om tariffavtale?», www.Arbeidslivet.no 3. mai 2019. Det er imidlertid enkelte andre eksempler på tariffavtaler for andre, lignende plattformer, som for matleveringstjenesten Lieferservice i Østerrike, se https://www.zeit.de/news/2019-09/17/oesterreichweltweit-erster-tarifvertrag-fuer-fahrradkuriere, og renholdstjenesten Hilfr i Danmark, se https://www.3f.dk/fagforening/fag/rengoeringsassistent-(privatansat)/overenskomsten-hilfrog.

Dom 4. februar 2019 fra Court of Appeal of Turin. For en kommentar, se https://ichinobrugnatelli.it/en/foodora-riders-comment-by-atty-marco-paoletti-on-the-judgment-of-thecourt-of-appeal-of-turin/.

Se Legislative Decree No. 81 of 15. June 2015 art. 2, som gjelder for visse arbeidsforhold med personlig arbeid. Det har siden 1970-tallet vært særregler i italiensk rett for en slik mellomkategori av økonomisk avhengige oppdragstakere, gjerne kalt «parasubordinato», se nærmere Edoardo Ales, «The Concept of Employee: The Position in Italy», i Waas/van Voss 2017 s. 351-375, særlig på s. 371-374, https://doi.org/10.5040/9781509912438.ch-017.

Dom 5. desember 2018 fra The High Court of Justice. Etter The Trade Union and Labour Relations (Consolidation) Act 1992 Schedule A1 er anerkjennelse av fagforeninger som part i kollektive forhandlinger betinget av at forhandlingene gjelder «workers». Det omfatter personer med arbeidsavtale («contract of employment») og personer med en annen arbeidskontrakt med personlig arbeidsplikt («any other contract whereby he undertakes to do or perform personally any work or service for another party to the contract who is not a professional client of his»), jf. Section 296 (1) a og b. Domstolen mente at EMK art. 11 (1) ikke gir en rett til kollektive forhandlinger i andre relasjoner enn arbeidsavtaler, og at avgrensningen til «workers» etter britisk rett uansett kunne legitimeres etter art. 11 (2) ut fra hensynet til næringsfriheten og behovet for frihet fra konkurransebegrensninger. 
konkurranserettslige skranker og menneskerettslige krav hver for seg (punkt 4 og 5). Til slutt vender jeg tilbake til arbeidstvistloven og mulige løsninger av avgrensningsproblemene i lys av denne internasjonale rettsutviklingen (punkt 6).

En terminologisk klargjøring er nødvendig. Når termen «oppdragstaker» brukes i det følgende, menes en person som formelt fremstår som en selvstendig oppdragstaker, samtidig som det ikke er klart at vedkommende reelt sett er arbeidstaker. Rene omgåelsestilfeller holdes altså utenfor. «Oppdragstaker» omfatter dermed både de genuint selvstendige, som reelt sett klart er oppdragstakere, og gråsonetilfellene, der realitetene etterlater usikkerhet. Drøftelsene fokuserer imidlertid særlig på den siste gruppen. Hvorvidt slike oppdragstakere kan og bør regnes som arbeidstakere etter arbeidstvistlovgivningen i større grad enn i dag, er noe av det artikkelen søker å avklare.

\section{Utgangspunktene og problemstillingene}

En adgang til å forhandle kollektivt behøver ikke noe særskilt rettslig grunnlag. Det følger av prinsipper om privat autonomi og avtalefrihet at enhver kan forhandle med sikte på å inngå avtaler. Det alminnelige rettslige utgangspunktet er derfor at oppdragstakere kan forhandle $\mathrm{i}$ fellesskap.

Konkurranserettslige regler setter imidlertid skranker for samarbeid som begrenser konkurransen i et marked. Konkurranseloven $§ 10$ forbyr konkurransebegrensende samarbeid mellom «foretak». ${ }^{25}$ Fordi forbudet er sentralt for en velfungerende konkurranse, har avtaler eller beslutninger i strid med forbudet ingen rettsvirkninger, jf. konkl. $§ 10$ (2). Bestemmelsen gjennomfører EØS-avtalen artikkel 53. Den skal derfor tolkes i tråd med det tilsvarende forbudet i EUs funksjonsmåtetraktat (TFEU) art. 101, og ved konflikt med andre regler om samme forhold har forbudet forrang, jf. EØS-loven $§ 2 .{ }^{26}$ Et viktig spørsmål er dermed om oppdragstakere er foretak i EU/EØS-rettslig forstand, slik at deres kollektive forhandlinger kan rammes av forbudet.

Adgangen til å forhandle om en bestemt type kollektiv avtale - en tariffavtale - har en helt særskilt betydning. Arbeidstvistlovgivningen gir rammeverket for forhandlinger og inngåelse av tariffavtaler, og anerkjenner tariffavtalens særlige rettsvirkninger og funksjoner.

Tariffavtaler særpreges ved å være bindende for medlemmene i de organisasjonene som inngår avtalen og ved å gi tvingende og ufravikelig regulering av avtaler mellom medlemsbundne. En tariffavtale har dermed normativ virkning i de individuelle arbeidsforholdene den omfatter. Arbeidstvistloven $\S 6$ gir ett klart uttrykk for det:

\footnotetext{
25

Lov 5. mars 2004 nr. 12 om konkurranse mellom foretak og kontroll med foretakssammenslutninger (konkurranseloven, konkl.).

26 Lov 27. november 1992 nr. 109 om gjennomføring i norsk rett av hoveddelen i avtale om Det europeiske $\emptyset$ konomiske samarbeidsområde (EØS) m.v. (EØS-loven). I det følgende viser jeg i første rekke til konkurranselovens bestemmelser.
} 
«Bestemmelse i arbeidsavtale som strider mot en tariffavtale som begge parter er bundet av, er ugyldig.» 27

Andre typer kollektive avtaler om vederlag og arbeidsvilkår har ikke tilsvarende rettsvirkninger. Bundethet beror i utgangspunktet på alminnelige avtalerettslige prinsipper. Dersom avtalen inngås av en sammenslutning, vil virkningene for medlemmer måtte avgjøres etter forenings- og kontraktsrettslige regler.

Tariffavtalers særskilte rettsvirkninger henger uløselig sammen med de funksjoner og hensyn avtalene skal ivareta. Tariffavtaler skal gi en enhetlig regulering av lønns- og arbeidsvilkår, regulere konkurransen i markedet for arbeidskraft og sikre stabilitet rundt denne reguleringen. ${ }^{28}$ Tariffavtaler har følgelig iboende - og ønskede - konkurranseregulerende funksjoner, særlig fordi de regulerer og utligner prisen på arbeidskraft. ${ }^{29}$

De hensynene som begrunner tariffavtaleregulering begrunner også at tariffavtaler skjermes fra konkurranserettslige regler. Regulering av «arbeids- og ansettelsesvilkår» er unntatt fra konkurranseloven, jf. $\S 3$. Unntaket er begrunnet i tradisjonen med å fastsette prisen på arbeidskraft gjennom tariffavtaler, og det er fremhevet at tilpasning og effektivisering først og fremst bør skje gjennom dette systemet. ${ }^{30}$

En rekke andre land har tilsvarende unntak eller andre regler som på lignende måte skjermer tariffavtaler fra konkurranserettslige forbud. ${ }^{31}$ Konkurransereglenes EU/EØSrettslige forankring reiser imidlertid spørsmål om slike nasjonale regler er i tråd med EU/EØS-retten. Det kom opp for EU-domstolen i Albany-trilogien. ${ }^{32}$ Der anerkjente EUdomstolen et såkalt «tariffunntak» for visse typer kollektive avtaler: Avtaler som er resultat av kollektive forhandlinger mellom «management and labour» og tar sikte på å forbedre «conditions of work and employment», faller utenfor forbudet mot konkurransebegrensende samarbeid på grunn av sin karakter og formål. ${ }^{33}$

27 Se tilsvarende tjtvl. § 13. Bestemmelsen er treffende betegnet av Skjønberg som «en mekanisme» for å oppnå tariffavtalens grunnleggende funksjon om å være normerende for individuelle arbeidsforhold, se Alexander Næss Skjønberg, «Den alminnelige regelen om ettervirkning av tariffavtaler», Arbeidsrett, 2019 s. 18-38 [Skjønberg 2019b], s. 21, https://doi.org/10.18261/issn.1504-3088-2019-01-02.

Alexander Næss Skjønberg, Fredsplikten i tarifforhold, 2019 [Skjønberg 2019a] s. 73-83, Stein Evju, «Ufravikelighet og tariffbundethet - historisk og aktuelt», Arbeidsnotater 2013:1 [Evju 2013] s. 18, og Paal Berg, Arbeidsrett, 1930 [Berg 1930] særlig s. 168-170 og s. 173-182. Se også forarbeidene til dagens arbeidstvistlov, Prop. 134 L (2010-2011) s. 7.

Se bl.a. HR-2016-2554-P Holship (avsnitt 146) og nærmere i Erling Hjelmeng, «The Concept of an 'Undertaking' - On the Borderline between Labour Law and Competition Law», i Bernard Johann Mulder mfl. (red.), Sui Generis. Festskrift til Stein Evju, 2016 s. 316-326 [Hjelmeng 2016], på s. 320.

Ot.prp. nr. 6 (2003-2004) s. 35.

31 For en komparativ oversikt, se generaladvokat Jacobs forslag til avgjørelse i Albany-trilogien, EU:C:1999:28 (avsnitt 80-112). Trilogien består av dom 19. september 1999, Albany, C-67/96, EU:C:1999:430, Brentjens, C-115/97, C-116/97 og C-117/97, EU:C:1999:434, og Drijvende Bokken, C-219/97, EU:C:1999:437.

Generaladvokat Jacobs betegnet dette som et «fundamental issue» med «potentially far-reaching implications» (avsnitt 79).

Se nærmere i punkt 4.1. 
Hvem som kan gis adgang til å forhandle tariffavtaler etter arbeidstvistloven, er altså et EU/EØS-rettslig spørsmål og beror særlig på tariffunntakets rekkevidde. Utenfor unntaket vil forbudet mot konkurransebegrensende samarbeid kunne være til hinder for kollektiv opptreden.

Et annet viktig utgangspunkt er at organisasjonsfriheten i dag innebærer en rett for fagforeninger («trade unions») til å forhandle kollektivt på vegne av sine medlemmer. Organisasjonsfriheten gjelder for enhver etter Den europeiske menneskerettskonvensjon (EMK) art. 11, FN-konvensjonen om sivile og politiske rettigheter (SP) art. 22 og FNkonvensjonen om $\varnothing$ konomiske, sosiale og kulturelle rettigheter (ØSK) art. 8. ${ }^{34}$ Bestemmelsene verner retten til å danne fagforeninger og forutsetter at disse skal kunne virke for medlemmenes interesser. ${ }^{35}$ Både arbeidstakere og oppdragstakere har rett til å slutte seg til en fagforening. ${ }^{36}$ Hvordan foreningen skal kunne virke for deres interesser, er et litt annet spørsmål.

Det er etablert at EMK art. 11 gir medlemmene rett til at fagforeninger blir hørt når de fremmer medlemmenes interesser - «trade unions should be heard». ${ }^{37}$ I praksis fra Den europeiske menneskerettsdomstol (EMD) ble adgang til kollektive forhandlinger lenge ansett som én mulig måte å gi effektivt vern av friheten til å fremme medlemmenes interesser, men ikke som absolutt nødvendig. ${ }^{38}$ Det sentrale var at fagforeninger måtte stå fritt, «in one way or another», til å søke å overtale arbeidsgivere til å lytte når de taler medlemmenes sak. ${ }^{39}$ Standpunktet ble imidlertid revurdert i saken Demir og Baykara mot Tyrkia. ${ }^{40}$ EMD slo der fast at en rett for fagforeninger til å forhandle kollektivt «with the employer» er blitt et nødvendig element $\mathrm{i}$ vernet av organisasjonsfriheten etter EMK art. $11 .{ }^{41} \mathrm{I}$ dag gir bestemmelsen dermed vern av to fundamentale rettigheter for fagforeninger, retten til å søke å overtale arbeidsgiver når de taler medlemmenes sak og retten til kollektive forhandlinger. ${ }^{42}$

34 Internasjonal konvensjon om sivile og politiske rettigheter, 1966, i kraft 23. mars 1976, og Internasjonal konvensjon om økonomiske, sosiale og kulturelle rettigheter, 1966, i kraft 3. januar 1976.

35 Grunnleggende om organisasjonsfrihet, se Stein Evju, Organisasjonsfrihet, tariffavtaler og streik, Oslo 1982 s. $40-48$.

36 D.J. Harris, M. O’Boyle og C. Warbrick, Law of the European Convention of Human Rights, 4. ed. 2018 [Harris/O’Boyle/Warbrick 2018] s. 722, https://doi.org/10.1093/he/9780198785163.001.0001.

37 Se blant annet EMDs dom 27. oktober 1975 i National Union of Belgian Police mot Belgia, klage nr. 4464/70 (avsnitt 39).

38 Se for eksempel EMDs dom 2. juli 2002 i Wilson, National Union of Journalists mfl. mot Storbritannia, klager nr. 30668/96, 20671/96 og 30678/960 (avsnitt 44).

Ibid. Mer om tidligere praksis, se Peer Lorenzen mfl., Den Europaiske Menneskerettighedskonvention, 3. utg. 2011 s. 911-912 og Harris/O’Boyle/Warbrick 2018 s. 728-729.

40 EMDs dom 12. november 2008 i Demir og Baykara mot Tyrkia, klage nr. 34503/97.

41 Demir og Baykara mot Tyrkia (avsnitt 154). Dette er fulgt opp i senere avgjørelser, se bl.a. EMDs dommer 30. april 2013 i Tymoshenko m.fl. mot Ukrania, klage nr. 49872/11, og 8. april 2014 i R.M.T. mot Storbritannia, klage nr. 31045/10. 
Forhandlingene skal være basert på frivillighet, det er følgelig ikke en rett til at en kollektiv avtale inngås.

Vernet av forhandlingsretten var et resultat av EMDs dynamiske tolkningsmetode. EMD la blant annet vekt på ESP og ILO-konvensjon nr. 98 om kollektive forhandlinger (ILO 98). ${ }^{43}$ Disse konvensjonene gir en uttrykkelig rett for «workers' organisations» til å forhandle kollektivt med «employers or employers' organisations» med sikte på «the regulation of terms and conditions of employment by means of collective agreements». ${ }^{44}$ I praksis fra ILOs organisasjonsfrihetskomité (CFA) er kollektive forhandlinger betegnet som et fundamentalt aspekt ved organisasjonsfriheten. ${ }^{45}$

Dette innebærer at en rett til kollektive forhandling er en del av norsk rett. Den rettslige forankringen er imidlertid sammensatt. EMK (samt SP og ØSK) gjelder som norsk rett med forrang ved motstrid med annen norsk rett, jf. menneskerettsloven $\S 3 .^{46}$ I tillegg er organisasjonsfriheten beskyttet i Grunnloven $\S 101 .{ }^{47}$ Høyesterett har avklart at bestemmelsen skal tolkes med utgangspunkt i EMK art. $11 .{ }^{48}$ ESP og ILO 98 har på sin side betydning for tolkningen av norsk rett i kraft av presumsjonsprinsippet. Disse konvensjonene med tilhørende praksis har dessuten betydning via EMK. EMDs tolkningsmetode viser at konvensjonene er relevante kilder for tolkningen av EMK art 11. Sammenhengene betyr at det enkelte menneskerettsinstrument ikke kan sees isolert. Gjennom Grunnloven og menneskerettsloven stiller konvensjonsbeskyttelsen visse krav til norsk rett. Innholdet i forhandlingsretten etter alle de nevnte menneskeinstrumentene har betydning ved fastleggelsen av hvilke krav som stilles.

Hvem som skal ha adgang til å forhandle kollektivt, dreier seg om forhandlingsrettens personelle rekkevidde. Det beror særlig på hva som er en «trade union» og hvem som anses som «workers». ${ }^{49}$ Det er imidlertid også et spørsmål om rettighetens nærmere innhold, sett opp mot norske regler. Er retten til å forhandle «collective agreements» en rett til å forhandle tariffavtaler i arbeidstvistlovens forstand, eller kan forhandling om andre typer kollektive avtaler være tilstrekkelig? I tillegg er det et spørsmål om hvilke inngrep i nasjonal rett som kan være legitime, både når det gjelder rekkevidde og innhold.

43 ILO-konvensjon nr. 98 om gjennomføring av prinsippene for organisasjonsretten og retten til å føre kollektive forhandlinger, 1949, i kraft 18. juli 1951, ratifisert av Norge 23. desember 1954.

Ordlyden er tilsvarende i ILO 98 art. 4 og ESP Part I og Part II art. 6 nr. 2.

45 Digest of decisions and principles of the Freedom of Association Committee of the Governing Body of the ILO (Sixth revised edition) 2018 [Digest 2018] (avsnitt 1313).

Lov 21. mai 1999 nr. 30 om styrking av menneskerettighetenes stilling i norsk rett (menneskerettsloven). Merk Norges forbehold mot ØSK artikkel $8 \mathrm{nr} .1$ bokstav d grunnet praksisen med tvungen lønnsnemnd. Kongeriket Norges Grunnlov 17. mai 1814 (Grunnloven). Bestemmelsen ble tatt inn ved reformen i 2014. HR-2016-2554-P (avsnitt 81). 
Her er det viktig å være seg bevisst at termer som betegner arbeidsutførende personer kan romme meningsforskjeller. Det er særlig tydelig i det engelske språket. Der betegner både «Worker» og «employee» arbeidsutførende personer, og begge benyttes til å angi rekkevidden for regler med arbeidsrettslig relevans. Mens «employee» normalt refererer til arbeidsavtaleforhold, er det mer åpent hva «worker» betyr. Det er velkjent at «worker» kan være en videre kategori enn «employee». Det er eksempler på at «worker» omfatter personer i andre typer av underordningsforhold enn regulære arbeidsavtaler. ${ }^{50}$ Det er også eksempler på at «worker» omfatter visse oppdragstakere. ${ }^{51}$ Men i prinsippet kan «worker» være en helt nøytral betegnelse på den som besitter arbeidskraften. Språklig sett kan både personer som selger sin arbeidskraft og personer som selger tjenester de selv utfører, anses som «worker». ${ }^{52}$ Det finnes enkelte eksempler på at «worker» rettslig sett brukes som en nøytral betegnelse. I California er grensen mellom arbeidstakere og oppdragstakere regulert av den såkalte «ABC»-testen. Slik testen er formulert, er «worker» den nøytrale betegnelsen på en person som utfører arbeid. ${ }^{53}$

«Worker» kan altså tenkes å omfatte både arbeidstakere og oppdragstakere. Tolkningen av «Worker» etter relevante internasjonale regler vil derfor stå sentralt i drøftelsene i punkt 4 og 5, særlig spørsmålet om begrepet omfatter (visse) oppdragstakere.

Et annet grunnleggende spørsmål er hvem kollektive forhandlinger for oppdragstakere eventuelt skal føres med. Å ha flere kunder er et viktig kjennetegn ved en genuint selvstendig oppdragstaker. Fravær av en klar arbeidstaker-arbeidsgiverrelasjon kan derfor gjøre det usikkert hvem som er den aktuelle motparten. Det er imidlertid minst to typesituasjoner der en naturlig motpart lar seg identifisere, og det er nettopp i slike situasjoner gråsonetilfeller gjerne oppstår.

Den ene situasjonen er der virksomheter som sysselsetter arbeidstakere, også benytter oppdragstakere i den løpende virksomheten. Oppdragstakeren kan i prinsippet stå fritt til å akseptere eller avslå oppdrag, mens det under oppdragets utførelse kan være større eller mindre likhetstrekk med arbeidstakerforhold. Da kan det være aktuelt å kreve forhandlinger om arbeidsvilkår under oppdragets varighet, blant annet om vederlag.

Den andre situasjonen er der én virksomhet - typisk en digital plattform - fungerer som et formidlingsledd mellom oppdragstakere og sluttkunder. Også her kan oppdragstakeren stå fritt til å akseptere eller avslå oppdrag, samtidig som forholdene under utførelse av arbeidet og

\footnotetext{
50 Se for eksempel rammedirektivet om arbeidsmiljø, 89/391/EF, art. 3 bokstav a, der «worker» er definert som «any person employed by an employer, including trainees and apprentices but excluding domestic servants».

Se for eksempel om britisk rett i note 24.

52 Det er utgangspunktet for drøftelsen i Breen Creighton og Shae McCrystal, «Who Is a Worker in International Law», 37 Comparative Labor law \& Policy Journal, s. 691-726 (2016) [Creighton/McCrystal 2016], se s. 691. Unemployment Insurance Code i California, godkjent av Guvernøren 18. september 2019.
} 
relasjonen til plattformen kan ha likhetstrekk med arbeidstakerforhold. I slike situasjoner kan det tenkes forhandlinger med plattformen om oppdragstakernes arbeidsvilkår. Dersom plattformen fastsetter vederlag og andre vilkår mellom oppdragstaker og sluttkunde, kan forhandlingene omfatte slike vilkår. Dersom oppdragstakerne selv bestemmer vilkår ut mot sluttkunde, kan plattformens vilkår for tilknytning og bruk være gjenstand for forhandlinger, som plattformens gebyr for kobling med kunden.

I det følgende er det særlig disse to typesituasjonene jeg har i tankene.

\section{Arbeidstvistloven og avgrensningsproblemene}

\subsection{Koblingen til individuelle arbeidsavtaler}

Arbeidstvistloven er utformet som et rammeverk for kollektiv regulering av lønns- og arbeidsvilkår i og for individuelle arbeidsavtaler, ikke for kollektiv regulering av arbeidsvilkår for oppdragstakere.

Tariffavtalens grunnleggende formål og funksjoner springer ut fra, og er knyttet til, den individuelle arbeidsavtalen mellom en arbeidsgiver og en arbeidstaker. Paal Berg har oppsummert at det var behovet for bindende og ufravikelig regulering av individuelle arbeidsavtaler som har begrunnet tariffavtalens særpreg og særlige rettsvirkninger, og som dermed «har skapt» tariffavtalen. ${ }^{54}$ Koblingen til arbeidstakerbegrepet og den individuelle arbeidsavtalen fremgår uttrykkelig av loven. Definisjonen av en tariffavtale har referanse til relasjonen mellom arbeidstaker og arbeidsgiver. Også på rettsvirkningssiden er tariffavtalen klart koblet til arbeidsavtaleforhold. Gjennom atvl. § 6 er medlemsbundethet og tvingende virkning til knyttet til partsforholdet og bestemmelsene «i arbeidsavtale». ${ }^{55}$

Spørsmålet er imidlertid om koblingen til individuelle arbeidsavtaler utelukker at oppdragstakere kan forhandle kollektivt etter arbeidstvistlovens regler. Det beror på hvilke nærmere avgrensninger som følger av lovens arbeidstakerbegrep og tariffavtalebegrep. Jeg drøfter derfor arbeidstakerbegrepet og tariffavtalebegrepet (punkt 3.2 og 3.3), med sikte på å tydeliggjøre avgrensningsproblemene i relasjon til oppdragstakere (punkt 3.4).

\subsection{Arbeidstakerbegrepet som avgrensning}

Arbeidstvistlovens definisjon av arbeidstaker (og arbeidsgiver) viser til arbeid «i tjeneste», jf. atvl. $\S 1$ bokstav a (og b). Det står i motsetning til oppdragstakeres selvstendige arbeid. Men som antydet innledningsvis er arbeidstakerbegrepet ingen skarp avgrensning. til arbeidsavtaler. Etter annet ledd skal den forståelsen av tariffavtalen som Arbeidsretten har lagt til grunn, også gjelde «for enhver arbeidsavtale som bygger på tariffavtalen». 
Dagens definisjon viderefører definisjonen av «arbeider» $\mathrm{i}$ arbeidstvistloven av $1927 \mathrm{i}$ språklig modernisert form. ${ }^{56}$ Arbeidsrettens praksis viser en lang tradisjon for å trekke grensen mot oppdragsforhold ut fra en bred vurdering av ulike momenter i lys av lovens formål. ${ }^{57}$ I ARD 1991 s. 140 heter det:

«Avgjørelsen av om det foreligger arbeidstagerforhold i lovens forstand må bygge på en helhetlig vurdering av ulike momenter, på grunnlag av lovens egen bestemmelse og de formål loven skal ivareta» (s. 170, kursivert her).

I samme avgjørelse understreket Arbeidsretten at vurderingen skal gjøres ut fra realitetene i arbeidsrelasjonene:

«Ved en vurdering i forhold til arbeidstvistlovens [i dag § 1 bokstav a] kan vekten ikke legges på det formelle. Den må legges på realiteten - om det er etablert tilknytningsforhold hvor vognmenn «utfører arbeid» i kommunens tjeneste» (s. 173, kursivert her).

Rettspraksis viser at flere momenter er relevante. Det legges vekt på om personene anses å ha personlig arbeidsplikt og være underlagt styring og kontroll. ${ }^{58}$ Andre momenter, som risikoen for arbeidsresultatet, kapitalinnsats, ordningen for vederlaget og stabiliteten i relasjonen, trekkes også inn. ${ }^{59}$ Vurderingen er rettet inn mot å avdekke om arbeidsrelasjonene har det underordnings- og avhengighetspreget som generelt anses å kjennetegne en arbeidstakers stilling. Det fremgår av rettens oppsummering i ARD 1991 s. 140:

«I det hele ser Arbeidsretten det slik at vognmennene står i et underordnings- og avhengighetsforhold til kommunen som svarer til det som ellers er et typisk og vesentlig trekk ved arbeidstagerforhold» (s. 172, kursivert her).

Denne avgrensningen mot oppdragsforhold kan måtte trekkes mellom grupper som utfører arbeid som saklig sett er omfattet av tariffavtalen. Personer som utfører arbeidet som arbeidstakere er omfattet, mens personer som utfører arbeidet som oppdragstakere faller utenfor. Her gir ARD 1968 s. 36 en illustrasjon. Bakgrunnen for tvisten var en omlegging av driften i Treschow-Fritzøe. Skogsarbeid utført av sesongengasjerte hestekjørere, traktorkjørere og skogsarbeidere i maskinlag hadde vært regulert i arbeidsavtaler, men ble søkt regulert i oppdragskontrakter. Bedriften og Skogbrukets Arbeidsgiverforening hevdet at arbeidet derfor ikke lenger var omfattet av skogbruksoverenskomsten, men Norsk Skog- og Landarbeiderforbund mente omleggingen var et fors $\varnothing \mathrm{k}$ på å omgå tarifforpliktelser. Det reiste spørsmål både om selve omleggingen var i strid med overenskomsten, og om de ulike gruppenes arbeidsrettslige status.

Lov 5. mai 1927 nr. 1 om arbeidstvister (arbeidstvistloven 1927), se Prop. 134 L (2010-2011) s. 72.

Se ARD 1991 s. 140, som har linjer tilbake til ARD 1968 s. 36 og ARD 1955 s. 117. 
Arbeidsretten fant at overenskomsten satte forbud mot at kjøring med hest ble utført som selvstendige oppdrag. Inngåelse av oppdragskontrakter med hestekjørerne var derfor tariffstridig. Vurderingen av arbeidsrettslig status falt ulikt ut for de tre gruppene. Heste- og traktorkjørere ble ansett for å ha «bevart sin arbeidstakerstilling» og være omfattet av overenskomsten. Begrunnelsen var at de nye kontraktene ikke «i nevneverdig grad har medført noen faktisk forandring» i deres «samlede arbeidsmessige status» overfor bedriften. ${ }^{60}$ Det gjaldt «reelt sett, så vel med hensyn til instruksjonsmyndighet, arbeidstid som personlig arbeidsplikt» (s. 42, kursivert i originalen). Arbeidsretten fant derimot at relasjonen mellom bedriften og skogsarbeidere i maskinlag «klart fremtrer som et forhold mellom en oppdragsgiver på den ene side og en selvstendig oppdragsmottaker på den annen side» (s. 43). Deres arbeid var falt derfor utenfor overenskomsten. Avgjørelsen ledet til at Skogbruksoverenskomsten i påfølgende tariffrevisjon fikk en arbeidstakerdefinisjon som bygget på skillet i denne avgjørelsen. ${ }^{61}$

Arbeidstakerbegrepet $\mathrm{i}$ arbeidstvistloven avgrenses med dette på tilsvarende måte som begrepet i arbeidsmiljøloven. Også dette begrepet avgrenses ved hjelp av helhetsvurdering av realitetene, ut fra lovens formål. De momentene vurderingen skal ta utgangspunkt $\mathrm{i}$, svarer til momenter trukket frem i Arbeidsrettens praksis. ${ }^{62}$ De momentene som er regnet som mest sentrale, personlig arbeidsplikt og arbeidsgivers ledelse og kontroll, viser at vurderingen særlig kretser rundt indikasjoner på et personlig underordningsforhold. Andre momenter, som stabiliteten i tilknytningen og antallet oppdragsgivere, viser at også forhold som indikerer $\varnothing$ konomisk avhengighet har relevans. ${ }^{63}$ Momentene er imidlertid veiledende, listen er ikke uttømmende, og Høyesterett har poengtert at vurderingen ikke skal være en «mekanisk anvendelse» av momentene. ${ }^{64}$ Høyesterett har i ulike sammenhenger understreket at avgrensningen må skje med utgangspunkt i formålet med de aktuelle reglene, og har betegnet dette som en «metodisk tilnærming». 65

60 Denne vurderingen av hestekjørerne hadde «gyldighet også for de enkeltstående eller individuelle traktørkjørere» (s. 42).

61 Definisjonen omfattet blant annet tømmerkjørere som utfører kjøring med egen hest og traktorkjørere som utfører kjøring med egen traktor, se omtale i ARD 1996 s. 91 (s. 92-93). Dommen gjaldt tolkningen og anvendelsen av en endret variant av definisjonen i dagjeldende Skogbruksoverenskomst. Den er i dag erstattet av Naturbruksoverenskomsten 2018-2020 mellom NHO/NHO Mat og Drikke og LO/Fellesforbundet, som har en enklere arbeidstakerdefinisjon i punkt 1.2.

Momentene er listet opp i Ot.prp. nr. 49 (2004-2005) s. 73. De ble først oppstilt i forarbeidene til ferieloven av 1947, og er senere lagt til grunn for dagens ferielov og arbeidsmiljølov, se også Ferielovkomiteens innstilling (1947) s. 20-21 og Ot.prp. nr. 54 (1986-87) s. 131.

Både underordning og økonomisk avhengighet er fremhevet som særtrekk ved arbeidsavtalen i forarbeidene til arbeidsmiljøloven, se Ot.prp. nr. 49 (2004-2005) s. 73.

Rt. 2015 s. 475 (avsnitt 65). Se for øvrig blant annet Rt. 2013 s. 354 (avsnitt 39). 
En slik tilnærming til avgrensningen gir samtidig arbeidstakerbegrepet, både i arbeidstvistloven og arbeidsmiljøloven, et fleksibelt preg. ${ }^{66}$ Henvisningen til formålet åpner for at begrepets grenser kan trekkes litt ulikt etter ulike regelsett. ${ }^{67}$ Begrepet $\mathrm{i}$ arbeidstvistloven kan følgelig tenkes å være videre enn i arbeidsmiljøloven, dersom lovens formål tilsier det.

I tilknytning til arbeidsmiljøloven er det dessuten lagt til grunn at begrepet skal kunne utvikle seg i takt med nye organisasjons- og tilknytningsformer og reflektere utviklingen på arbeidsmarkedet. Valget om å beholde definisjonen uendret i 2005 var begrunnet nettopp i «arbeidstakerbegrepets innebygde fleksibilitet og elastisitet $\mathrm{i}$ forhold til utviklingen i arbeidslivet», og det ble forutsatt at fremtidig praksis «reflekterer en fremtidig utvikling på arbeidsmarkedet». ${ }^{68}$ Når arbeidstvistlovens begrep er definert på tilsvarende måte og har et tilsvarende fleksibelt preg, må forutsetningen også være aktuell for denne lovens del. Et viktig spørsmål er dermed hvilken veiledning arbeidstvistlovens formål gir for gråsonetilfellene på dagens arbeidsmarked.

Lovens formål er knyttet til de funksjoner og hensyn tariffavtalene ivaretar. Ifølge forarbeidene til dagens lov er et «sentralt hensyn ... å vareta arbeidstaker- og arbeidsgiversidens interesse i å nå frem til en bindende regulering ved tariffavtale, noe som bidrar til å sikre stabilitet i arbeidslivet». ${ }^{69}$ Begrunnelsen for tariffavtalers konkurranseregulerende og stabiliserende funksjoner henger videre sammen med preget av maktubalanse - eller asymmetri - i de individuelle arbeidsrelasjonene som skal kunne reguleres kollektivt. ${ }^{70}$ En sentral side ved maktubalansen er det personlige underordnings- og avhengighetsforholdet som oppstår når én stiller sin arbeidskraft til rådighet for en annen og underlegger seg dennes styringsrett. Et annet aspekt er at partene har ulike sosioøkonomiske posisjoner i utgangspunktet. ${ }^{71}$ Den som råder over produksjonsmidler og kan velge blant flere tilbydere av arbeidskraft, har en mer gunstig markedsposisjon enn den som trenger tilgang til andres produksjonsmidler for å kunne utnytte sin arbeidskraft effektivt, og som ofte må konkurrere blant flere med tilsvarende arbeidskraft å tilby. Adgang til kollektiv opptreden og tariffregulering skal motvirke at besittere av arbeidskraft underbyr hverandre i et «race to the bottom». ${ }^{72}$ Med andre ord er én side ved formålet å motvirke konsekvenser av frie

Se nærmere Marianne Jenum Hotvedt, «Arbeidstaker - quo vadis? Den nyere utviklingen av arbeidstakerbegrepet», Tidsskrift for Rettsvitenskap, 2018 s. 42-103 [Hotvedt 2018], særlig s. 51, https://doi.org/10.18261/issn.1504-3096-2018-01-02.

Se særlig NOU 2004: 5 s. 163.

Prop. 134 L (2010-2011) s. 7. Se også i punkt 2.

Se til det følgende Skjønberg 2019a s. 74-77. Her finnes også utfyllende referanser til annen litteratur.

Om betydningen av ulike sosioøkonomiske posisjoner, se også Stein Evju, «Arbeidsrett og styringsrett - et perspektiv», Arbeidsrett og arbeidsliv, Bind 1 s. 3-32 (2003), s. 6.

Skjønberg 2019a s. 75-76. 
markedskrefter i partsforhold preget av økonomisk ubalanse og systematiske skjevheter i forhandlingsposisjonene.

Denne delen av formålet har klar relevans for oppdragstakere i gråsonen. Økonomisk ubalanse og skjeve forhandlingsposisjoner kan foreligge uavhengig av om den enkelte inngår avtaler som etablerer et tydelig underordningsforhold eller avtaler med større grad av selvstendighet. Formålet kan følgelig tjene som argument for at personer i en slik situasjon regnes som arbeidstakere med adgang til forhandlinger etter arbeidstvistlovens rammeverk.

Rettspraksis gir en viss støtte for at arbeidstvistlovens formål kan begrunne argumenter som åpner for en utvidet forståelse av arbeidstakerbegrepet. I ARD 1991 s. 140 anerkjente Arbeidsretten at tariffpartenes forutsetninger kan ha vekt ved avgrensningen av lovens arbeidstakerbegrep, og begrunnet det i lovens formål:

«Etter arbeidstvistloven er et sentralt formål at det gjennom tariffavtaleregulering skal etableres gjensidig forpliktende regulering som gir vilkårstrygghet og stabilitet for partene i og for dem som omfattes av avtalene. Ved en vurdering i forhold til [i dag $§ 1$ bokstav a] må det etter rettens syn også være rom for å legge vekt på det som har vært partenes intensjoner med og forutsetninger for avtalereguleringen» (s. 173).

Saken gjaldt nettopp om personer i gråsonen skulle regnes som arbeidstakere. Spørsmålet var om to kollektive avtaler mellom Norsk Kommuneforbund og Oslo kommune om arbeidsvilkår for «vognmenn» var tariffavtaler i kraft av å regulere arbeidstakerforhold. Vognmennene var sjåfører som eide ett kjøretøy og selv kjørte dette. De ble behandlet som selvstendig næringsdrivende etter offentligrettslige regler om løyveplikt og skatt. Men i den kollektive reguleringen, som hadde røtter tilbake til 1940-tallet, hadde partene forutsatt at avtalene var tariffavtaler og at vognmennene var arbeidstakere i kommunen (s. 167 og 169). Realitetene viste etter Arbeidsrettens syn at vognmennene utførte arbeid i kommunens tjeneste, blant annet fordi de ble ansett å ha personlig arbeidsplikt og være underlagt kommunens styring og kontroll. Partenes forutsetning ble imidlertid trukket inn som et supplerende argument. Vognmennene ble etter «en samlet vurdering» regnet som arbeidstakere (s. 173).

Lovens formål og tariffpartenes forutsetninger bidro altså til å underbygge at det forelå arbeidstakerforhold i lovens forstand. Når partenes forutsetninger er relevante, er konsekvensen at det blir vanskelig å skille klart mellom lovens og tariffpartenes arbeidstakerbegrep. Hvordan partene mener begrepet $b \phi r$ avgrenses, vil da kunne få betydning for hvordan det etter loven skal avgrenses. Dette er et viktig poeng, som jeg kommer tilbake til.

\subsection{Tariffavtalebegrepet som avgrensning}

I arbeidstvistloven er tariffavtalebegrepet definert som «en avtale mellom en fagforening og en arbeidsgiver eller arbeidsgiverforening om arbeids- og lønnsvilkår eller andre 
arbeidsforhold», jf. atvl. $§ 1$ bokstav e. ${ }^{73}$ I det ligger både et krav til partene og et krav til innholdet. Begge kravene er koblet til arbeidsavtaleforhold.

Når det gjelder krav til partene, må det på den ene siden være en fagforening. Fagforening er definert med referanse til arbeidstakerbegrepet og den individuelle arbeidsavtalen. Den må være en sammenslutning av «arbeidstakere eller av arbeidstakeres foreninger» og ha til formål å «vareta arbeidstakernes interesser overfor deres arbeidsgivere», jf. atvl. § 1 bokstav c. ${ }^{74}$ For øvrig synes det ikke å stilles andre krav enn at sammenslutningen må opptre uavhengig av arbeidsgiveren. Kravene til selve sammenslutningen er lavere enn det som ellers kreves for at en forening skal ha rettsevne. ${ }^{75}$ Referansen til arbeidstakere synes å gi en avgrensning mot oppdragstakere. En sammenslutning av selvstendige oppdragstakere er i utgangspunktet ingen fagforening. Men fagforeningsbegrepet er likevel ikke helt enkelt å avgrense.

Det kan ikke utelukkes at en sammenslutning av oppdragstakere rettslig sett er en fagforening. En slik sammenslutning kan, vurdert ut fra realitetene på individuelt nivå, bli regnet som en sammenslutning av arbeidstakere med formål å fremme deres interesser overfor arbeidsgiveren. Et eksempel fra Paris kan være illustrerende. Der har bud fra Foodora, Deliveroo og en lignende plattform - Uber Eat - dannet en sammenslutning for «selvstendige» bud, Collectif des Livreurs Autonomes Parisiens (CLAP). ${ }^{76}$ CLAP organiserer aksjoner rettet mot plattformenes dårlige - og stadig verre - arbeidsvilkår. ${ }^{77}$ Dersom budenes relasjon til plattformen i realiteten er en arbeidsavtale, slik tilfellet er for Foodora i Norge, ville CLAP være en fagforening etter norsk rett.

Det er videre ikke tvilsomt at en sammenslutning som består av både arbeidstakere og oppdragstakere kan være en fagforening i lovens forstand. En rekke etablerte arbeidstakerorganisasjoner organiserer oppdragstakere i tillegg til arbeidstakere. Det gjelder for eksempel Norsk Journalistlag, Den norske legeforeningen og Creo - forbundet for kunst

73 Tariffavtalebegrepet rommer også et formkrav. For at avtalen skal ha gyldighet som tariffavtale, må den være skriftlig, jf. atvl. $\S 4$. Det er i tillegg et spørsmål om det kreves tariffavtalehensikt, se nærmere Tron Løkken Sundet, Tariffavtalen - Utvalgte emner, 2014 [Sundet 2014] s. 59-62.

Merk at tjenestetvistloven stiller ytterligere krav til partsforholdet på det statlige området, med blant annet krav til organisasjonene på arbeidstakersiden om representativitet og størrelse, jf. § 2 jf. § 3 . Her har partene imidlertid en uttrykkelig plikt til forhandlinger.

Det kreves en viss grad av fellesskap arbeidstakerne imellom, og at sammenslutningen opptrer uavhengig av arbeidsgiveren. Begrepet omfatter dermed også uformelle sammenslutninger, uten vedtekter eller styre, samt sammenslutninger som er opprettet midlertidig eller dannet ad hoc, se nærmere Stein Evju, «Tariffavtalebegrepet - prosessuelt og materielt», Arbeidsrett og arbeidsliv Bind 1 s. 112-123 (2005) [Evju 2005] s. 113 og Sundet 2014 s. 36-38.

Se CLAPs side på Facebook, www.facebook.com/clap75/?ref=br_rs.

En større aksjon ble for eksempel gjennomført under VM i fotball sommeren 2018, se «French Uber Eats, Deliveroo, Foodora workers strike during World Cup final», www.Politico.eu 11. juli 2018. Det er også senere eksempler på aksjoner mot ensidige endringer av betalingsbetingelsene til budenes ugunst, se «French Deliveroo drivers strike over pay dispute», www.france24.com 8. august 2019. 
og kultur. ${ }^{78}$ De enkelte medlemmene trenger ikke bare tilhøre én gruppe. En journalist kan for eksempel være ansatt i en avis, for så å arbeide som selvstendig, eventuelt kombinere ansettelsen med tilleggsoppdrag. En fastlege regnes normalt som oppdragstaker i sin kurative virksomhet, men kombinerer det i en del tilfeller med en deltidsansettelse som kommunelege. Slike «blandede» organisasjoner arbeider presumptivt for å fremme begge gruppers interesser. ${ }^{79}$ Organisasjonen regnes imidlertid kun som en fagforening når den opptrer på vegne av medlemmer som er arbeidstakere. Når den opptrer på vegne av medlemmer som rettslig sett er oppdragstakere, kan den ikke forhandle tariffavtaler. Det har sammenheng med kravet til tariffavtalers innhold.

Etter legaldefinisjonen må avtalen gjelde «arbeids- og lønnsvilkår eller andre arbeidsforhold» for å være en tariffavtale. Tillegget «eller andre arbeidsforhold» innebærer at avtaler som kun gir regler om forholdet mellom tariffpartene - såkalte obligatoriske bestemmelser - er omfattet av tariffavtalebegrepet. ${ }^{80}$ «Arbeids- og lønnsvilkår» viser imidlertid til vilkår i arbeidsavtaleforhold. Kravet til innholdet forstås vidt og omfatter alle typer vilkår som er ment å gjelde for og i individuelle arbeidsavtaler, de såkalte normative bestemmelsene. ${ }^{81}$ Det kreves ingen helhetlig regulering, i prinsippet kan én slik bestemmelse være tilstrekkelig. Men det må dreie seg om bestemmelser for ubestemte arbeidsforhold. ${ }^{82}$

Dette innebærer en avgrensning mot regulering av selvstendige oppdragsforhold. En avtale som kun regulerer arbeidsvilkår for personer som klart er selvstendige, er opplagt ikke en tariffavtale. Det gjelder selv om avtalen er fremforhandlet av en fagforening. ${ }^{83}$ Når Den norske legeforening forhandler rammeavtale for fastlegeordningen med KS, fremgår det at avtalen ikke pretenderer å regulere arbeidstakerforhold eller ha normativ virkning. ${ }^{84}$

På nettsiden til Norsk Journalistlag heter det for eksempel: «Norsk Journalistlag organiserer redaksjonelle medarbeidere, også ledere og frilansere, som har journalistikk som yrke», se https://www.nj.no/om-norskjournalistlag/.

På Legeforeningens nettside heter det for eksempel: «Legeforeningen arbeider for å styrke medlemmenes arbeidsvilkår som ansatte og næringsdrivende», se https://beta.legeforeningen.no/jus-og-arbeidsliv/, og på Creo nettside heter det: «Vi arbeider for å sikre medlemmene våre bedre lønns, - og arbeidsvilkår, enten de er arbeidstakere eller selvstendig næringsdrivende», se https://creokultur.no/medlemskapicreo/.

Det fremgår av forarbeidene til den første arbeidstvistloven, se nærmere Stein Evju, «Tariffavtaler som rettslig fenomen», i Torgeir Aarvaag Stokke, Kristine Nergaard og Stein Evju, Det kollektive arbeidslivet, 2. utg. 2013 s. 119-172, s. 128, og Skjønberg 2019b s. 21. Tjenestetvistloven $§ 11$ forstås tilsvarende. Evju 2005 s. 113-114.

En avtale som kun tar sikte på å fastslå hva som skal gjelde i ett eller flere bestemte arbeidsforhold, er ingen tariffavtale, se ARD 1983 s. 235.

Se til illustrasjon ARD 1955 s. 117. Der ble en avtale mellom vegvesenet i Troms fylke og Norsk Arbeidsmandsforbund om snøbrøyting i Troms ikke ansett som en tariffavtale. Arbeidsretten mente brøyterne «må ansees som selvstendige næringsdrivende» i relasjon til fylket, og at avtalen dermed «ikke gjelder en avtale om lønns- og arbeidsvilkår i en annens tjeneste» (s. 121).

Rammeavtale mellom KS og Den norske legeforening om allmennlegepraksis i kommunene ASA 4310 for perioden 1. januar 2013 til 31. desember 2014 (prolongert frem til 31. august 2019), med en individuell «mønsteravtale» som vedlegg I, Individuell avtale om allmennpraksis i fastlegeordning for selvstendig noringsdrivende fastlege. 
Denne avgrensningen mot selvstendige oppdragsforhold er prinsipielt sett tvingende for tariffpartene. I ARD 1991 s. 140 la Arbeidsretten til grunn at det ikke er opp til tariffpartene å avtale hvem som er arbeidstaker, og fortsatte:

«Det må - som et alminnelig utgangspunkt - legges til grunn at en avtale, for å være en tariffavtale i lovens forstand, må gi bestemmelser som nevnt med anvendelse for forhold som materielt sett kan vurderes som arbeidstagerforhold, også i lovens egen forstand.» ${ }^{85}$

Prinsipielt sett er det følgelig ikke opp til tariffpartene å bestemme om det avtalen regulerer, er arbeidstaker- eller oppdragsforhold. Avgjørende for om avtalen er en tariffavtale, er om den regulerer det som $i$ arbeidstvistlovens forstand er arbeidstakerforhold.

\subsection{Nærmere om avgrensningsproblemene}

Tross disse avklaringene reiser arbeidstvistloven flere avgrensningsproblemer. Problemene ligger i forlengelsen av det som hittil er diskutert - arbeidstakerbegrepet og tariffavtalebegrepet. Problemene knytter seg imidlertid også til tariffavtalebegrepets rettsvirkningsside - hvor langt den normative virkningen strekker seg.

Den første, nokså grunnleggende, komplikasjon er at arbeidstakerbegrepet i prinsippet krever en individuell vurdering, mens en kollektiv avtale gir bestemmelser på gruppenivå, for ubestemte arbeidsforhold. Særlig de momentene som indikerer $\varnothing$ konomisk avhengighet er vinklet mot den individuelle arbeidsrelasjonen og setter fokus på hvor tett og stabil tilknytningen er. Disse momentene kan lett slå ulikt ut for personer som utfører samme type arbeid på ellers like vilkår. Det skaper en utfordring for vurderingen av om - og eventuelt i hvilken grad - en kollektiv regulering av arbeidsforhold i gråsonen i realiteten gjelder arbeidstakerforhold. Slik momentene er formulert, er det vanskelig å gjøre en vurdering på gruppenivå som tar hensyn til sosioøkonomiske maktskjevheter.

Et neste spørsmål er hvordan man skal vurdere en kollektiv avtale som regulerer oppdragsforhold $i$ tillegg til arbeidstakerforhold. Et eksempel er journalistavtalene mellom Norsk Journalistlag (NJ) og Mediebedriftenes Landsforening (MBL) og Næringslivets Hovedorganisasjon (NHO), som tidligere inkluderte et eget bilag om frilansere. Nå er bilaget erstattet av en separat rammeavtale om kjøp og salg av frilansstoff. ${ }^{86}$ Rettspraksis viser at en avtale ikke mister sin karakter av å være tariffavtale selv om den - i tillegg til normative bestemmelser om arbeidstakerforhold - også inneholder andre typer bestemmelser, som uforpliktende utsagn eller vilkår for bestemte arbeidsforhold. ${ }^{87}$ Arbeidsretten har imidlertid

ARD 1991 s. 140 (s. 169). Reservasjonen for avtaler med rent obligatoriske bestemmelser er imidlertid nevnt.

Rammeavtale mellom Norsk Journalistlag og Mediebedriftenes Landsforening om kjøp og salg av frilansstoff [Frilansavtalen], i kraft 1. april 2018 og gjeldende «inntil videre», se $§ 13$. Se nærmere om endringen på https://www.mediebedriftene.no/arbeidsliv/rammeavtale-frilans/.

Det er lagt til grunn i ARD 1988 s. 151, ARD 1991 s. 140 og ARD 2013 s. 89.
} 
uttalt at de normative bestemmelsene må være «de dominerende elementene». ${ }^{88}$ En avtale som regulerer oppdragsforhold i tillegg til arbeidstakerforhold, må derfor kunne regnes som en tariffavtale. Men det leder til avgrensningsproblemer på rettsvirkningssiden.

Som forklart i punkt 3.1 er tariffavtalens normative virkning avgrenset til de bestemmelsene som regulerer arbeidstakerforhold. Tariffavtalte bestemmelser om selvstendige oppdragsforhold vil dermed ikke ha normativ virkning. I den nevnte frilansavtalen heter det uttrykkelig at avtalen ikke er omfattet av Hovedavtalen og tariffavtalesystemet. ${ }^{89}$ Men dersom oppdragsforholdene ligger i gråsonen, er det ikke enkelt å avgrense den normative virkningen. Da beror det på en nærmere vurdering om bestemmelsene i realiteten regulerer arbeidstakerforhold. Som nevnt ovenfor er det ikke opplagt hvordan man skal kunne vurdere dette på gruppenivå uten å miste hensynet til sosioøkonomiske maktskjevheter av syne.

Selv om bestemmelsene i realiteten anses å gjelde oppdragsforhold og ikke har regulær normativ virkning, kan bestemmelsene ha rettsvirkninger som kan gi ulike former for indirekte normativ effekt i oppdragsforhold.

Tariffavtalens parter har plikt til å etterleve alle de avtalte bestemmelsene på kontraktsrettslig grunnlag, inkludert bestemmelser som regulerer oppdragsforhold. En arbeidsgiver som selv er part i avtalen, vil derfor være forpliktet overfor sin motpart i tariffavtalen til å etterleve bestemmelsene om oppdragsforhold.

Videre er det veletablert at en tariffbundet arbeidsgiver har plikt etter tariffavtalen til ikke å anvende tariffstridige vilkår overfor arbeidstakere som ikke er medlemsbundet, såkalte «utenforstående arbeidstakere». ${ }^{90}$ Det kan reises spørsmål om en tariffbundet arbeidsgiver på tilsvarende måte kan ha en plikt etter tariffavtalen til ikke å anvende vilkår overfor oppdragstakere som strider mot avtalens bestemmelser om oppdragsforhold. Spørsmålet er, så langt jeg kan se, verken berørt i rettspraksis eller teori.

Tariffavtalte bestemmelser om oppdragsforhold kan dessuten få betydning for tolkningen av den individuelle oppdragsavtalen. I teorien er det lagt til grunn at det gjelder en presumsjon om at utenforstående arbeidstakeres individuelle avtaler utfylles med de lønns- og arbeidsvilkår som gjelder etter arbeidsgivers tariffavtale, med mindre det er holdepunkter for en annen løsning. ${ }^{91}$ Der oppdragstakerens motpart er en tariffbundet arbeidsgiver, kan det tenkes en tilsvarende presumsjon for at denne ikke inngår oppdragsavtaler med innhold som strider mot bestemmelser (om oppdragsforhold) i tariffavtalen. Heller ikke dette spørsmålet synes å være behandlet i rettspraksis eller teori.

88 ARD 1988 s. 151 (s. 164) og ARD 2013 s. 89 (avsnitt 64).

89 Frilansavtalen $\S 1$.

90 ARD 1922 s. 50, se nærmere Alexander Næss Skjønberg, «Tariffavtalers virkning for utenforstående arbeidstakere», Arbeidsrett 2011 s. 1-80 [Skjønberg 2011], særlig s. 12-14.

91 Skjønberg 2011 særlig s. 49-50. Standpunktet har støtte i eldre teori, se Alexander Næss Skjønberg, Eirik Hognestad og Marianne Jenum Hotvedt, Individuell arbeidsrett, 2. utg. 2017 s. 87-88. 
Særskilte vanskeligheter oppstår dersom en avtale kun regulerer oppdragsforhold i gråsonen som om de er arbeidstakerforhold. Da er det uklart om avtalen overhodet er en tariffavtale (med normativ virkning), og et viktig spørsmål er hvilken betydning partenes forutsetninger har i den forbindelse. Dommen om vognmennene i ARD 1991 s. 140 berører akkurat dette. Det var i denne dommen Arbeidsretten understreket at det som «alminnelig utgangspunkt» ikke er opp til partene å avtale hvem som er arbeidstakere, og på den måten regulere hvorvidt avtalen er en tariffavtale. ${ }^{92}$ I forlengelsen heter det imidlertid:

\begin{abstract}
«Dersom en avtale gir bestemmelser som - innholdsmessig og med hensyn til hvem de gjelder for - etter sin art faller inn under arbeidstvistlovens regler, er avtalen også en tariffavtale i lovens forstand. Dens rettslige karakter endres i denne henseende ikke selv om avtalen dessuten måtte inneholde bestemmelser av annen art. Hvis en avtale først er en tariffavtale, vil dens parter forsåvidt også ha en adgang til å regulere narmere hvem som skal omfattes av den, således også hvem som skal regnes som arbeidstagere i tariffavtalens forstand» (s. 170, kursivert her).
\end{abstract}

De to første setningene bekrefter det som er forklart ovenfor, at en avtale som regulerer oppdragsforhold i tillegg til arbeidstakerforhold, mister ikke derved sin karakter av å være en tariffavtale. Det er mer uklart hva som ligger i den siste setningen, om tariffpartenes adgang til å regulere nærmere hvem skal regnes som arbeidstakere i tariffavtalens forstand. Tariffpartene har klar adgang til å regulere hvilke arbeidstakere en tariffavtale gjelder for, men det var ikke det saken gjaldt. Spørsmålet var om den kollektive reguleringen overhodet gjaldt arbeidstakere. Denne konteksten åpner for å forstå uttalelsen slik at partene tilkjennes en viss adgang til å bestemme hvilke arbeidsforhold som skal være gjenstand for tariffregulering. Uttalelser om arbeidstakerbegrepet senere i dommen synes å gi støtte for det. Som vist i punkt 3.2 åpnet Arbeidsretten for å legge vekt på tariffpartenes intensjoner ved avgrensningen av hvem som er arbeidstaker i arbeidstvistlovens forstand, noe som gjør det vanskelig å skille klart mellom lovens arbeidstakerbegrep og hvem tariffpartene mener bør være arbeidstakere. ${ }^{93} \AA$ la tariffpartenes forutsetninger få betydning er i realiteten å tilkjenne dem en viss frihet til å bestemme hvilke arbeidsforhold som skal kunne tariffreguleres.

Uttalelsen i dommen er i høyden en antydning av en slik frihet for partene. Uttalelsen fremstår dessuten som et obiter dictum, siden vognmennene etter en vurdering av realitetene ble ansett som arbeidstakere. Jeg kommer likevel tilbake til dette i avslutningen i punkt 6.

\title{
$4 \quad$ Konkurranserettslige skranker
}

\subsection{Forbudet mot konkurransebegrensende samarbeid og tariffunntaket}

Spørsmålet i det følgende er om det EU/EØS-rettslige forbudet mot konkurransebegrensende samarbeid åpner for at visse oppdragstakere kan gis adgang til å forhandle tariffavtaler i 
nasjonal rett. Det beror dels på hva slags samordnet opptreden som rammes av forbudet, og dels på hva slags kollektive forhandlinger som skjermes gjennom tariffunntaket. Spørsmålene henger imidlertid nært sammen.

Forbudet gjelder koordinering mellom to eller flere «foretak», enten ved avtale, samordnet opptreden eller beslutninger truffet av «sammenslutninger av foretak» som har til «formål eller virkning å hindre, innskrenke eller vri konkurransen», jf. konkl. § 10 (1).

Foretaksbegrepet avgrenser hvilke aktørers opptreden som omfattes. Begrepet er EUrettslig og forstås funksjonelt, det omfatter enhver enhet - også fysiske personer - som driver $\varnothing$ konomisk virksomhet, uavhengig av rettslig status og finansieringsform. ${ }^{94}$ Som $\varnothing$ konomisk virksomhet regnes det å tilby varer eller tjenester på et marked. ${ }^{95}$ En arbeidsgiver/oppdragsgiver er derfor et foretak når den driver økonomisk virksomhet på markedet for varer og tjenester. En selvstendig oppdragstaker er også i utgangspunktet et foretak. Vedkommende er i prinsippet en $\varnothing$ konomisk enhet som tilbyr tjenester. ${ }^{96}$ En arbeidstaker er derimot ikke et foretak, men anses integrert i arbeidsgiverforetaket så lenge arbeidsavtalen løper. Det er dels begrunnet gjennom doktrinen om økonomisk enhet, som innebærer at flere juridiske eller fysiske personer kan anses som samme enhet i den grad de er underlagt en annens avgjørende innflytelse eller kontroll. ${ }^{97}$ Arbeidstakeren betraktes ikke som en egen $\varnothing$ konomisk enhet særlig fordi arbeidet er underlagt arbeidsgiverens kontroll. ${ }^{98}$ Men dels er det vist til at markedet for arbeidskraft skiller seg fra markedet for varer og tjenester og ikke er ment å bli regulert av konkurransereglene. ${ }^{99}$ Med den begrunnelsen vil verken arbeidstakeres virksomhet som tilbydere av arbeidskraft eller arbeidsgiveres virksomhet som etterspørrere av arbeidskraft omfattes av konkurransereglene. ${ }^{100}$ Her ligger sammenhengen med tariffunntaket, som kan sees som et utslag av avgrensningen av foretaksbegrepet. ${ }^{101}$

Det følger av fast praksis i EU-domstolen, se bl.a. dom 23. april 1991, Höfner \& Elser mot Marcroton, C41/90, EU:C:1991:161 (avsnitt 21). Nærmere om foretaksbegrepet, se Richard Wish og David Bailey, Competition Law, 9. ed. 2018 [Wish/Bailey 2018], s. 84-90, https://doi.org/10.1093/lawocl/9780198779063.001.0001, og Eirik Østerud «Konkurranserettslige beslutninger av sammenslutninger av foretak», Tidsskrift for Rettsvitenskap nr. 2-3 2016 s. 176-215 [Østerud 2016], særlig s. 183-184, https://doi.org/10.18261/issn.1504-3096-2016-02-03-03.

Dom 12. september 2000, Pavlov mfl., C-180/98 og C-184/98, EU:C:2000:428 (avsnitt 75). Se bl.a. dom 28. februar 2013, Ordem dos Técnicos Oficiais de Contas, C-1/12, EU:C:2013:127 (avsnitt 36-38).

97 Alison Jones og Brenda Sufrin, EU Competition Law, 5. ed. 2014 s. 137-139, [XX Oppdateres i korrekturen, venteliste på NY utgave] https://doi.org/10.1093/he/9780198824657.001.0001.

Se bla. dom 16. september 1999, Весu, C-22/98, EU:C:1999:419 (avsnitt 26). Olav Kolstad og Anders Ryssdal, Norsk konkurranserett. Bind 1 Atferdsregler og strukturkontroll, 2007 [Kolstad/Ryssdal 2007] s. 175 er kritisk til denne begrunnelsen.

Denne begrunnelsen er utviklet i generaladvokat Jacobs forslag til avgjørelse i Albany (særlig avsnitt 209217). Kolstad/Ryssdal 2007 s. 175.

Det er illustrerende at Wish/Bailey 2018 behandler tariffunntaket og Albany som ledd i fremstillingen av foretaksbegrepet, se s. 90-92. Se tilsvarende Kolstad/Ryssdal 2007 s. 174-177 og Hjelmeng 2016. 
En fagforening vil på denne bakgrunn normalt ikke utgjøre en «sammenslutning av foretak» når den opptrer på vegne av medlemmer som er arbeidstakere. ${ }^{102}$ Foreningen kan imidlertid være en «sammenslutning av foretak» dersom den opptrer på vegne av medlemmer som er oppdragstakere. ${ }^{103}$ Beslutninger truffet i en slik funksjon vil kunne rammes av forbudet, og kollektiv opptreden kan i seg selv utgjøre en avtale eller samordnet opptreden i strid med forbudet. ${ }^{104}$ Kollektive forhandlinger for oppdragstakere representerer altså en type koordinering som er konkurranserettslig problematisk - så langt oppdragstakerne regnes som foretak.

Koordineringen må videre ha konkurransebegrensende «formål eller virkning» på vare- og tjenestemarkedet for være forbudt. Dette er betegnet som et kvalifisert krav:

Formålsalternativet anvendes kun der potensialet for å skade konkurransen er særlig alvorlig og virkningsalternativet krever merkbar skade. ${ }^{105}$ Prissamarbeid, det vil si samarbeid som direkte eller indirekte fastsetter priser eller andre forretningsvilkår, er særskilt fremhevet i bokstav a og er ansett å ha konkurransebegrensende formål. ${ }^{106}$ Dermed vil forhandlinger om vederlaget for selvstendige oppdragstakere som et klart utgangspunkt være forbudt.

Forhandlinger om andre typer arbeidsvilkår rammes ikke nødvendigvis, da må koordineringens formål eller virkning vurderes nærmere. ${ }^{107}$ Både prissamarbeid og annen koordinering kan fritas fra forbudet på nærmere vilkår etter konkl. § 10 (3). Forutsetningen er at de gunstige effektene for partene og markedet oppveier den reduserte konkurransen. ${ }^{108}$ Siden prissamarbeid regnes som en alvorlig konkurransebegrensning, vil det normalt kreves bevis for betydelige gevinster for at unntak skal være aktuelt. ${ }^{109}$

Dette er bakgrunnen for at fagforeninger som også organiserer oppdragstakere, vanligvis avstår fra å søke å forhandle eller anbefale bestemte vederlag. ${ }^{110}$ Frilansavtalen for

102 Forbudet rammer derfor ikke koordinering mellom arbeidstakere, og normalt heller ikke koordinering mellom arbeidstakere og en arbeidstakerorganisasjon, mellom ulike arbeidstakerorganisasjoner eller mellom arbeidstakere/arbeidstakerorganisasjoner og én enkelt arbeidsgiver, se Hjelmeng 2016 s. 319 og Eirik Østerud, «Konkurransereglenes anvendelse på tariffavtaler og boikott som arbeidskampmiddel Status etter EFTA-domstolens og Høyesteretts avgjørelser i 'Holship-saken'», Arbeidsrett, 2017 s. 1-30 [Østerud 2017], særlig s. 13 og 18, https://doi.org/10.18261/issn.1504-3088-2017-01-01.

Organisasjonen kan også være et foretak i den grad den driver økonomisk virksomhet på egne vegne, se sak E-14/15 Holship mot Norsk Transportarbeiderforbund (avsnitt 73).

Praksis viser at «avtale»/«samordnet opptreden» tolkes vidt og har konvergert med «beslutning», slik at sistnevnte har liten eller ingen selvstendig betydning, se Østerud 2016 s. 192-203.

Østerud 2017 s. 13-14.

106 Nærmere om «price-fixing», se Wish/Bailey 2018 særlig s. 128-132.

107 Se nærmere Kolstad/Ryssdal 2007 om formålsvurderingen på s. 271-274 og om virkningsvurderingen på s. $274-287$.

108 Se nærmere Kolstad/Ryssdal 2007, særlig s. 294-295.

109 Kolstad/Ryssdal 2007 s. 271.

110 Vurderinger fra fagforeninger i kultursektoren er beskrevet i Kristine Nergaard og Beate Sletvold Øiestad, Fastsettelse av lønn og honorar for korttidsoppdrag på det kunstneriske feltet, Fafo-notat 2016:19, s. 1819. 
journalister inneholder for eksempel ingen bestemte satser for vederlag, men nøyer seg med å sette noen premisser for individuelle avtaler om blant annet honorar og utgiftsdekning. ${ }^{111}$

Det neste spørsmålet er hva slags kollektive forhandlinger som skjermes gjennom tariffunntaket. Unntaket for «arbeids- og ansettelsesvilkår» i konkl. § 3 er knyttet til arbeidstakerforhold. Etter forarbeidene gjelder unntaket kollektiv regulering av vilkår for arbeidstakere, mens oppdragsforhold faller utenfor. ${ }^{112}$ Unntaket er imidlertid også avgrenset ut fra innholdet i reguleringen. Det er ikke tariffavtaler som sådan som skjermes, men de bestemmelsene i tariffavtaler som regulerer «prisen» på arbeid og derved har betydning for konkurransen om arbeidskraft. Bestemmelser i tariffavtale som direkte regulerer $\varnothing v$ vige sider av konkurransen, kan derfor rammes av forbudet selv om de er fastsatt i en tariffavtale. ${ }^{113}$ Bestemmelsen skal forstås i tråd med det såkalte «tariffunntaket» som ble anerkjent i Albanytrilogien.

Albany-trilogien reiste spørsmål om forbudet mot konkurransebegrensende samarbeid kom til anvendelse på beslutninger truffet av arbeidsgiver- og arbeidstakerorganisasjoner innenfor rammen av en kollektiv avtale, som ledet til at tilslutning til et fond for tjenestepensjon ble obligatorisk i bransjen. ${ }^{114}$ EU-domstolen oppstilte et unntak ut fra en formålsbestemt og helhetlig tolkning av traktatgrunnlaget. Den poengterte at formålet med EU-samarbeidet ikke bare er å sikre et fritt indre marked, men også et høyt sosialt beskyttelsesnivå, og viste til betydningen av kollektive forhandlinger og avtaler mellom arbeidslivets parter. For å sikre de viktige sosialpolitiske målene med slike avtaler, må de unntas i kraft av sin karakter og formål:

«... the social policy objectives pursued by such agreements would be seriously undermined if management and labour were subject to [i dag TFEU art. 101(1)] when seeking jointly to adopt measures to improve conditions of work and employment.

It therefore follows from an interpretation of the provisions of the Treaty as a whole which is both effective and consistent that agreements concluded in the context of collective negotiations between management and labour in pursuit of such objectives must, by virtue of their nature and purpose, be regarded as falling outside the scope of [i dag TFEU art. 101(1)]» (avsnitt 59 og 60, kursivert her).

111 For fastleger er situasjonen nokså særegen. Der forhandler Den norske legeforeningen med staten/KS om visse $\varnothing$ konomiske vilkår i den såkalte «statsavtalen». Betingelsene er imidlertid knyttet til pasientens rett til dekning av utgifter til helsehjelp og nærmere regulert i lov 24. juni $2011 \mathrm{nr}$. 30 om helse- og omsorgstjenester m.m. med tilhørende forskrift 29. august nr. 842 om fastlegeordningen i kommunene.

I tidligere lov gjaldt unntaket «lønns- og arbeidsvilkår i tjeneste hos andre», og denne forståelsen er videreført, se Ot.prp. nr. 6 (2003-2004) s. 34-35. Se også Harald Evensen og Eivind Sæveraas (red.) Konkurranseloven og EØS-konkurranseloven med kommentarer, 2009 s. 56-57.

Ot.prp. nr. 6 (2003-2004) s. 35.

114 Albany (avsnitt 52). Tariffpartene hadde opprettet ordningen og anmodet myndighetene om å gjøre den obligatorisk. Tvisten oppstod da tekstilbedriften Albany etter hvert nektet å betale bidrag til fondet. 
Unntakets rekkevidde beror følgelig på avtalens karakter og formål. Avtalen må være en kollektiv overenskomst mellom arbeidslivets organisasjoner, og formålet må være å bedre arbeids- og ansettelsesvilkår.

Kravet til formålet skal forstås vidt og omfatter brede kategorier som lønn, arbeidstid og andre arbeidsforhold. ${ }^{115}$ I norsk sammenheng har Arbeidsretten ansett det sentralt om bestemmelsene er «egnede foranstaltninger» til å forbedre arbeids- og ansettelsesvilkårene. ${ }^{116}$

I kravet til avtalens karakter ligger det en avgrensning av hvem unntaket omfatter. Opprinnelig var det ikke opplagt at unntaket var avgrenset til arbeidstakere og regulering av vilkår i arbeidsavtaler. Albany-trilogien ga en noe uskarp avgrensning av hvem organisasjonene kan representere og hvilke gruppers arbeidsforhold de kan regulere. Dette er angitt som «organisations representing employers and workers»/«negotiations between management and labour» og som «conditions of work and employment». ${ }^{117}$

I den senere avgjørelsen i Pavlov mfl. ble terminologien imidlertid strammet inn. Sakene reiste spørsmål om tariffunntaket skulle få anvendelse på lignende beslutninger (om en obligatorisk tilleggspensjonsordning) truffet av en representativ organisasjon for utøvere av et liberalt erverv. EU-domstolen avviste at unntaket kunne få anvendelse:

«Such exclusion from the scope of [i dag TFEU art. 101(1)] cannot be applied to an agreement which, whilst being intended, like the agreement at issue in the main proceedings, to guarantee a certain level of pension to all the members of a profession and thus to improve one aspect of their working conditions, namely their remuneration, is not concluded in the context of collective bargaining between employers and employees» (avsnitt 68, kursivert her). ${ }^{118}$

Å knytte kravet til avtalens karakter til «employees» fremfor «workers» kobler tariffunntaket klarere til arbeidsavtaleforhold. Innstrammingen er ikke kommentert eller nærmere begrunnet. Domstolen påpekte bare fraværet av traktatbestemmelser som tilskynder til kollektive avtaler for å forbedre arbeidsvilkår for utøvere av liberale erverv (avsnitt 69).

Den strammere formuleringen er senere også benyttet av EFTA-domstolen. ${ }^{119}$ Det er likevel ikke gitt at kollektive forhandlinger for alle oppdragstakere faller utenfor tariffunntaket. Tross klargjøringen av at tariffunntaket er koblet til arbeidstakerbegrepet og arbeidsavtaleforhold, reiser det seg lignende avgrensningsspørsmål som etter arbeidstvistloven. Et spørsmål er hvor grensen mellom (det EU-rettslige) arbeidstakerbegrepet og foretaksbegrepet skal trekkes. Et annet er hvordan man skal vurdere kollektive forhandlinger med blandet formål, altså der fagforeningen organiserer oppdragstakere i tillegg til arbeidstakere og avtalen regulerer begge gruppers arbeidsvilkår. Disse spørsmålene ble

\footnotetext{
115 Se nærmere EFTA-domstolens avgjørelse i «KLP-saken», sak E-8/00 LO (avsnitt 53).

116 ARD 2002 s. 90 KLP (avsnitt 661).

117 Albany (avsnitt 55-67, kursivert her). Se tilsvarende i de andre avgjørelsene i trilogien, Brentjens (avsnitt 52-57) og Drijvende Bokken (avsnitt 42-47).

Beslutningene ble likevel ikke rammet av forbudet fordi de ikke ble ansett å ha merkbar konkurransebegrensende virkning, se Pavlov mfl. (avsnitt 90-97).

EFTA-domstolens avgjørelse i «KLP-saken», sak E-8/00 LO (avsnitt 49).
} 
vurdert av EU-domstolen i saken FNV Kunsten. Dommen skal derfor drøftes nærmere (punkt 4.2) med sikte på å klarlegge om konkurranserettslige regler åpner for tariffregulering av oppdragsforhold i gråsonen (punkt 4.3).

\subsection{EU-domstolens avgjørelse i FNV Kunsten}

Saken gjaldt en avtale mellom en arbeidsgiverorganisasjon og to arbeidstakerorganisasjoner med minimumshonorarer for vikarer for orkestermusikere. Avtalen omfattet arbeid utført av både arbeidstakere (ansatte vikarmusikere) og oppdragstakere (vikarmusikere som formelt arbeidet etter oppdragskontrakter), og avtalen fastsatte ulike honorarer for de to gruppene. ${ }^{120}$ Oppdragstakerne var medlemmer i fagforeningene, og de utførte samme type arbeid og fylte samme funksjoner orkesteret som de ansatte vikarmusikerne. ${ }^{121}$ Bakgrunnen var at nederlandsk rett åpnet for at bestemmelser om arbeidsavtaler i kollektive avtaler mellom arbeidsmarkedspartene kunne gis anvendelse for oppdragsavtaler. ${ }^{122}$

To spørsmål var reist for EU-domstolen. Det første var om bestemmelsene for oppdragstakere falt utenfor forbudet mot konkurransebegrensende samarbeid i TFEU art. 101 (1) allerede fordi de var nedfelt i en kollektiv avtale mellom arbeidsgiver- og arbeidstakerorganisasjoner («a collective labour agreement»). Det andre spørsmålet - gitt at det første ble besvart negativt - var om bestemmelsene falt utenfor fordi de også hadde til formål å bedre arbeidsvilkårene for de arbeidstakerne som var omfattet av avtalen, samt om det hadde betydning om arbeidstakeres arbeidsvilkår ble forbedret direkte eller indirekte. Domstolen valgte imidlertid å behandle dem under ett (avsnitt 21).

EU-domstolen konkluderte med at tariffunntaket kunne anvendes på bestemmelser for oppdragstakere som var «falske selvstendige» («false self-employed»). Vurderingen kretset først og fremst rundt avtalens karakter.

EU-domstolen fremhevet at avtaler på vegne av selvstendige oppdragstakere i prinsippet faller utenfor tariffunntaket. Den viste til at tjenesteytere prinsipielt sett er foretak i konkurransereglenes forstand, også når de utfører samme type aktivitet som arbeidstakere (avsnitt 27). ${ }^{123}$ En organisasjon som opptrer på vegne av selvstendige oppdragstakere, opptrer derfor ikke som en fagforening, men som en sammenslutning av foretak (avsnitt 28). Domstolen trakk videre frem at traktatbestemmelsene om fremme av dialog mellom arbeidslivets parter gjelder «management and labour», og ikke oppmuntrer til dialog mellom arbeidsgivere og selvstendige oppdragstakere om forbedring av deres arbeidsvilkår (avsnitt

120 Honoraret til vikarer som var oppdragstakere skulle minst svare til honoraret til ansatte vikarer med et tillegg på 16 prosent.

121 I dommen heter det at oppdragstakerne som utfører «the same activity as that employer's employed workers» (avsnitt 21). 
30). Ut fra disse - for så vidt kjente - utgangspunktene oppstilte domstolen en tydelig avgrensning av tariffunntaket:

$\ll \ldots$ it follows that a provision of a collective labour agreement, such as that at issue in the main proceedings, in so far as it was concluded by an employees' organisation in the name, and on behalf, of the self-employed services providers who are its members, does not constitute the result of a collective negotiation between employers and employees, and cannot be excluded, by reason of its nature, from the scope of Article 101(1) TFEU» (avsnitt 30).

Det prinsipielle utgangspunktet er følgelig at kollektiv regulering av arbeidsvilkår for selvstendige oppdragstakere ikke omfattes av tariffunntaket i kraft av avtalens karakter, selv om avtalen er inngått mellom arbeidsgiver- og arbeidstakerorganisasjoner og bestemmelsene inngår i en tariffavtale.

EU-domstolen fortsatte med en viktig nyansering. Utgangspunktet var ikke til hinder for å anvende tariffunntaket der oppdragstakerne i realiteten er «falske selvstendige», hvilket vil si $i$ en sammenlignbar situasjon med arbeidstakere:

«That finding cannot, however, prevent such a provision of a collective labour agreement from being regarded also as the result of dialogue between management and labour if the service providers, in the name and on behalf of whom the trade union negotiated, are in fact 'false selfemployed', that is to say, service providers in a situation comparable to that of employees» (avsnitt 31 , kursivert her).

Resonnementet bak er sammensatt. Men gjennomgående fokuserte domstolen på situasjonen under utfфrelse av det konkrete oppdraget, ikke på personens samlede opptreden på markedet. Som nevnt gjaldt de aktuelle oppdragene samme type arbeid som ansatte vikarer og fylte tilsvarende funksjoner.

Domstolen viste til den faktiske situasjonen på arbeidsmarkedet, der det ikke alltid er enkelt å ta stilling til om oppdragstakere er foretak. Videre minnet domstolen om at status som foretak kan falle bort dersom vedkommende er helt avhengig av prinsipalen, ikke tar del i den $\emptyset$ konomiske risikoen og er integrert i dennes virksomhet (avsnitt 32 og 33). På den annen side viste domstolen til at status som «worker» verken beror på formell status eller på nasjonal rett. Det må gjøres en nærmere vurdering der det vesentlige er om en person i en viss periode utfører arbeid mot vederlag for en annen under dennes ledelse (avsnitt 34 og 35). Ut fra praksis om begge begrepene oppstilte domstolen en form for syntese:

«It follows that the status of 'worker' within the meaning of EU law is not affected by the fact that a person has been hired as a self-employed person under national law, for tax, administrative or organisational reasons, as long as that persons acts under the direction of his employer as regards, in particular, his freedom to choose the time, place and content of his work (see judgment in Allonby, EU:C:2004:18, paragraph 72), does not share in the employer's commercial risks (judgment in Agegate, C-3/87, EU:C:1989:650, paragraph 36), and, for the duration of that relationship, forms an integral part of that employer's undertaking, so forming an economic unit 
with that undertaking (see judgment in Becu and Others, C-22/98, EU:C:1999:419, paragraph 26)» (avsnitt 36). ${ }^{124}$

Nyanseringen fremstår etter dette som et uttrykk for at begrepene har en funksjonell karakter. Når både foretaksbegrepet og «worker» vurderes ut fra realitetene, må også tariffunntaket avgrenses slik og kunne omfatte en «falsk» oppdragstaker. At vurderingen gjøres konkret, for den enkelte arbeidsrelasjon, er også i tråd med en funksjonell tilnærming. En oppdragstaker kan dermed være «falsk selvstendig» under utførelse av ett oppdrag, men genuint selvstendig $i$ andre sammenhenger.

Vurderingen av avtalens formål var helt kortfattet og knyttet til vurderingen av avtalens karakter. Domstolen konstaterte at kravet til formålet bare kunne være oppfylt der oppdragstakerne er «falske selvstendige» (avsnitt 37). Den fant det samtidig klart at bestemmelsene om minimumshonorarer bidro direkte til forbedring av oppdragstakernes arbeidsvilkår (avsnitt 39). ${ }^{125}$ Så lenge musikerne var «falske selvstendige», var bestemmelsene derfor omfattet av tariffunntaket.

EU-domstolen overlot til nasjonale domstoler å ta stilling til om vikarmusikerne var «falske selvstendige» i relasjonen til orkesteret. ${ }^{126}$ Avslutningsvis poengterte den likevel at nasjonale domstolene må forsikre seg om at («ascertain that») oppdragstakerne er ekte foretak («genuine 'undertakings'»), og fortsatte:

«... in particular, that their relationship with the orchestra concerned is not one of subordination during the contractual relationship, so that they enjoy more independence and flexibility than employees who perform the same activity, as regards the determination of the working hours, the place and manner of performing the tasks assigned, in other words, the rehearsals and concerts» (avsnitt 37, kursivert her).

Her understreker EU-domstolen betydningen av å vurdere om oppdragstakerne er genuint selvstendige. Nasjonale domstoler må sarlig forsikre seg om at det ikke er tydelig preg av underordning under utførelse av oppdraget, men større selvstendighet og fleksibilitet sammenlignet med arbeidstakere som utfører samme type aktivitet.

\subsection{Omfatter tariffunntaket oppdragstakere i gråsonen?}

FNV Kunsten klargjør at verken formell klassifisering eller nasjonal rett er avgjørende for hvem som omfattes av tariffunntaket. Unntaket kan omfatte personer som formelt fremstår som oppdragstakere, og som i nasjonalrettslige sammenhenger - for eksempel etter skatte- og

124 De momentene som er trukket inn og de sakene som er nevnt, knytter seg til både foretaksbegrepet og arbeidstakerbegrepet.

125 Bestemmelsene bidro ikke bare til høyere betaling, men muliggjorde også deltakelse i en tjenestepensjonsordning, se FNV Kunsten (avsnitt 40).

126 Vikarmusikerne ble i etterkant av EU-domstolens avgjørelse av den nederlandske ankeinstansen vurdert til å være falske selvstendige, se dom fra Gerechtshof's-Gravenhage (Gerechtshof den Haag) 15. september 2015, ECLI:NL:GHDHA:2015:2305. Domstolen viste blant annet til at de måtte forholde seg til samme timeplan for $\emptyset$ velser mv. og samme instruksjoner fra dirigenten som de ansatte vikarmusikerne. 
trygderettslige regler - regnes som det. Det avgjørende er en fellesskapsrettslig vurdering av realitetene i den konkrete arbeidsrelasjonen.

For øvrig er avgjørelsen uklar og omdiskutert. Det kan reises spørsmål om den etablerer en ny mellomkategori som omfattes av tariffunntaket. Ut fra generaladvokat Wahls uttalelse i saken har flere imidlertid tatt til orde for at avgjørelsen «bare» er uttrykk for at grensen mellom foretak/selvstendig oppdragstaker og arbeidstaker skal trekkes ut fra de konkrete realitetene. ${ }^{127}$ Fra konkurranserettslig hold er det hevdet at avgjørelsen ikke forandrer tariffunntaket, men snevrer inn foretaksbegrepet slik at tariffunntaket tøyes. ${ }^{128}$ Uansett etterlater avgjørelsen tvil om hvor grensen for tariffunntaket mer nøyaktig går.

En konkret vurdering av realitetene synes å innebære at tariffunntaket kan omfatte i hvert fall noen oppdragstakere. «Falske selvstendige» er av EU-domstolen beskrevet å være i en situasjon som er sammenlignbar med arbeidstakeres. Formuleringen skulle tilsi at realitetene ikke behøver å samsvare fullt ut med arbeidstakerforhold.

Retningslinjene for avgrensningen rommer to perspektiver gjennom syntesen av begrepene foretak og «worker». Både momenter som viser klar selvstendighet som markedsaktør, og momenter som innebærer et tydelig underordningsforhold, er trukket inn. Grensen belyses dermed ved hjelp av ytterpunktene på skalaen. Men det gis liten rettledning for hvor på skalaen grensen går, idet de konkrete grensedragningene overlates til nasjonal rett. Det skaper uklarhet om hvor langt inn i gråsonen tariffunntaket kan anvendes.

EU-domstolens avsluttende føring for vurderingen er imidlertid interessant og kan sees som en viktig veiledning: Nasjonale domstoler skal særlig forsikre seg om oppdragstakerne er genuint selvstendige. Domstolen hadde allerede anerkjent at arbeidsrelasjonene befinner seg på en glideskala som skaper vanskelige avgrensningsproblemer. Dette kan derfor forstås som en bevisst prioritering av ett perspektiv: Det sentrale spørsmålet er om tariffunntaket ikke kan anvendes fordi det dreier seg om genuint selvstendige foretak. Da behøver det ikke være avgjørende om det er klare tegn til et underordningsforhold. Selv visse likhetstrekk med arbeidstakerforhold kan skape tvil om hvorvidt det dreier seg om genuint selvstendige foretak.

Etter mitt syn gir FNV Kunsten dermed holdepunkter for at tariffunntaket først og fremst skal avgrenses mot de klart selvstendige oppdragstakerne. I så fall kan tvil være tilstrekkelig til å gi tariffunntaket anvendelse. Samlet sett er det likevel nokså usikkert i hvilken grad tariffunntaket åpner for å skjerme kollektive forhandlinger for oppdragstakere i gråsonen fra forbudet mot konkurransebegrensende samarbeid.

127 Se blant annet Natalie Videbæk Munkholm og Christian Højer Schjøler, «Platform Work and the Danish Model - Legal Perspectives», Nordic Journal of Commercial Law, 2018 s. 117-145, på s. 133, https://doi.org/10.5278/ojs.njcl.v0i1.2487, og Eva Grosheide og Beryl ter Haare, «Employee-like worker: Competitive entrepreneur or submissive employee? Reflections on ECJ, C-413/13, FNV Kunsten Informatie», Maciej Łaga, Stefano Bellomo, Nicola Gundt, José Maria Miranda Boto (eds.), Labour Law and Social Rights in Europe: The Jurisprudence of International Courts. Selected Judgements, 2017 s. 2140, på s. 36-37.

Se blant annet Hjelmeng 2016 s. 324. 


\title{
5 Menneskerettslige krav
}

\subsection{Retten til kollektive forhandlinger og inngrepsadgangen}

Spørsmålet her er om menneskerettsbeskyttelsen av retten til kollektive forhandlinger krever at visse oppdragstakere skal gis adgang til å forhandle tariffavtaler. Som forklart i punkt 2 beror det på rettighetens nærmere rekkevidde og innhold. Siden vernet har ulik form i ulike konvensjoner, synes det å reise litt ulike spørsmål.

Etter EMK art. 11 er spørsmålet hvilke sammenslutninger som regnes som «trade unions», hvem de kan opptre på vegne av, og hva det betyr å «bargain collectively with the employer». Nærmere rekkevidde og innhold må sees i lys av inngrepsadgangen etter EMK art. 11 nr. 2, som tillater innskrenkninger som er foreskrevet ved lov og nødvendige i et demokratisk samfunn av hensyn til blant annet andres rettigheter og friheter. ${ }^{129}$

Etter ILO 98 og ESP er spørsmålet hvem som regnes som «workers» og hva det betyr å forhandle «with a view to the regulation of terms and conditions of employment by means of collective agreements». ESP fastsetter i Part I prinsippet om at «[a]ll workers and employers have the right to bargain collectively», og statenes forpliktelser er presisert slik i Part II art. 6:

«With a view to ensuring the effective exercise of the right to bargain collectively, the Parties undertake

1. to promote joint consultation between workers and employers;

2. to promote, where necessary and appropriate, machinery for voluntary negotiations between employers or employers' organisations and workers' organisations, with a view to the regulation of terms and conditions of employment by means of collective agreements,

$[3 . .]$.

ESP art. G gir en inngrepsadgang som er avgrenset på lignende måte som EMK art. 11 nr. 2. Beskyttelsen etter ILO 98 har ikke form av en rettighet med inngrepsadgang, men realiteten behøver ikke dermed være ulik. I art. 4 er statenes forpliktelse angitt slik:

\begin{abstract}
«Measures appropriate to national conditions shall be taken, where necessary, to encourage and promote the full development and utilisation of machinery for voluntary negotiation between employers or employers' organisations and workers' organisations, with a view to the regulation of terms and conditions of employment by means of collective agreements.»
\end{abstract}

Det er først og fremst ILO 98 og ESP art. 6 som gir veiledning i relasjon til oppdragstakere. Den videre drøftelsen er derfor konsentrert om disse to instrumentene (punkt 5.2 og punkt 5.3), med en samlet vurdering til slutt (punkt 5.4).

129 Vilkårene for begrensninger er nogenlunde parallelle i EMK art. 11 nr. 2, SP art. 22 nr. 2 og ØSK art. 8 nr. 1 bokstav a. Det er imidlertid en særskilt unntaksadgang for medlemmer av væpnede styrker, politi og statsforvaltning, jf. EMK art. 11, SP art. 22 nr. 2 og ØSK art. 8 nr. 2. 


\subsection{Nærmere om retten etter ILO 98}

Koblingen mellom retten til kollektive forhandlinger og organisasjonsfrihet gjør det naturlig å se rekkevidden av retten etter ILO 98 i sammenheng med ILO-konvensjon nr. 87 om organisasjonsfrihet (ILO 87). ${ }^{130}$

Hvem som skal regnes som «workers», er ikke nærmere regulert. Men i ILO 87 art. 1 er det understreket at organisasjonsretten gjelder for «workers ... without distinction whatsoever». Det kan trekke i retning av en vid forståelse. Motparten er imidlertid betegnet som «employers» i begge konvensjoner, og både organisasjonsfriheten og forhandlingsretten er knyttet til «employment». ${ }^{131}$ Det taler for en avgrensning til arbeidsavtaleforhold.

Konvensjonenes oppbygning og forhistorie taler for at «worker» rekker noe videre. ${ }^{132}$ Det ble lagt til grunn at offentlige tjenestemenn er omfattet av ILO 87, og det ble kun gjort et særskilt unntak for væpnede styrker og politi i art. $9 \mathrm{nr}$. 1. Det forutsetter en vid forståelse av «worker», ettersom flere nasjonale rettssystemer regner offentlige tjenestemenns arbeidsforhold for å hvile på offentligrettslig grunnlag og ikke ha basis i en arbeidsavtale. ${ }^{133}$ Diskusjonene forut for vedtakelsen av konvensjonen gir ingen holdepunkter for at referansen til «employment» var ment som en avgrensning. ${ }^{134}$ Creighton/McCrystal mener forhistorien derved gjør det klart at «workers» omfatter alle som utfører arbeid, uavhengig av om det foreligger en avtale og av avtaletypen. ${ }^{135}$ Standpunktet er diskutabelt. At personer i andre typer underordningsforhold er omfattet, er ikke ensbetydende med oppdragstakere også må være omfattet.

Nyere praksis fra ILOs håndhevelsesorganer gir imidlertid klar støtte for at oppdragstakere i utgangspunktet regnes som «workers». Både Ekspertkomiteen (CEACR) ${ }^{136}$ og Organisasjonsfrihetskomiteen (CFA) har uttalt at «workers» etter ILO 87 omfatter «selfemployed workers». CFA har oppsummert sitt syn slik:

«By virtue of the principles of freedom of association, all workers - with the sole exception of members of the armed forces and the police - should have the right to establish and join organizations of their own choosing. The criterion for determining the persons covered by that

130 ILO-konvensjon nr. 87 om foreningsfrihet og beskyttelse av organisasjonsretten, 1948, i kraft 4. juli 1950, ratifisert av Norge 30. juni 1949.

131 ILO 98 art. $1 \mathrm{nr} .1$ og art. 4.

132 Se nærmere Creighton/McCrystal 2016 s. 694-701.

133 Poenget har også relevans for ILO 98, selv om forholdet til offentlige tjenestemenn der er regulert på annen måte. Etter art. 6 berører konvensjonen ikke forholdene for statlige tjenestemenn, men skal heller ikke svekke deres stilling.

134 Creighton/McCrystal 2016 s. 700-701.

135 Creighton/McCrystal 2016 uttaler på s. 706 at konvensjonene «apply to all 'workers' in the broadest sense of the term; that is, they apply irrespective of the kind of contractual arrangement (if any) under which individuals are engaged...». Det er verd å merke seg at forfatterne legger dette til grunn for samtlige åtte kjernekonvensjoner i ILO-systemet.

The Committee of Experts on the Application of Conventions and Recommendations. Både den og CFA har viktige roller i oppfølgningen av statenes etterlevelse av ILO 87 og 98. 
right, therefore, is not based on the existence of an employment relationship, which is often nonexistent, for example in the case of agricultural workers, self-employed workers in general or those who practice liberal professions, who should nevertheless enjoy the right to organize.» 137

CEACR har nokså nylig lagt en tilsvarende tolkning til grunn for retten til kollektive forhandlinger etter ILO 98. I sin General Survey fra 2012 fremhevet komiteen at retten er «general in scope», men ikke alltid respekteres i praksis, og poengterte så:

«This situation has given the Committee cause to recall that the right to collective bargaining should also cover organizations representing the following categories of workers: prison staff, fire service personnel, seafarers, self-employed and temporary workers, outsourced or contract workers, apprentices, non-resident workers and part-time workers, dockworkers, agricultural workers, workers in religious or charity organizations, domestic workers, workers in EPZs and migrant workers» (s. 85, kursivert her).

Det må derfor være rimelig avklart at retten til kollektive forhandlinger etter ILO 98 omfatter oppdragstakere, i hvert fall som et utgangspunkt.

Rettighetens innhold for oppdragstakere er ikke like klarlagt. I en klage mot Korea synes CFA imidlertid å forutsette at oppdragstakere som er omfattet av rettigheten, skal ha adgang til samme type kollektive forhandlinger som arbeidstakere. ${ }^{138}$ Klagen gjaldt trailersjåfører (heavy goods vehicle drivers) som i koreansk høyesterett var ansett som selvstendige oppdragstakere. Deres organisasjoner var dermed ikke anerkjent som fagforeninger med tilgang til de kollektive forhandlingsmekanismene i nasjonal lovgivning (Trade Union and Labour Relations Adjustment Act, TULRAA). Klagen rettet seg blant annet mot den manglende tilgangen til kollektive forhandlinger. CFA påpekte først, uten nærmere begrunnelse, at klagen gjaldt en form for omgåelse: «'illegal dispatch’ workers, i.e. precarious workers in disguised employment relationships» (avsnitt 454). At sjåførene eide eget kjøretøy, selv stod ansvarlige for påløpte kostnader og arbeidet uten spesifikke instruksjoner fra selskapene de kjørte for, gir likevel et inntrykk av at det gjaldt oppdragsforhold i gråsonen. ${ }^{139}$ Komiteen tok utgangspunkt $i$ at organisasjonsfriheten omfatter «all workers - with the sole exception of members of the armed forces and the police» og dermed omfatter trailersjåfører. Fra det sluttet komiteen direkte («consequently») at sjåførene måtte stå fritt til å danne organisasjoner til å fremme sine interesser, «including organizations formed under the TULRAA» (avsnitt 461). På den bakgrunn ble Korea oppfordret til å sikre at oppdragstakere

137 Digest 2018 (avsnitt 387, kursivert her). Se tilsvarende fra CEACR i General Survey on the fundamental Conventions Concerning Rights at Work in Light of the ILO Declaration on Social Justice for a Fair Globalization, 2008, Report III, Part 1B [General Survey 2012] s. 19. Her sier CEACR uttrykkelig at «selfemployed workers» er omfattet, og understreker at «the only exceptions» statene kan gjøre, er for væpnede styrker og politi.

CFA rapport 363, klage i sak 2602 mot Korea fra Korean Metalworkers' Federation (KMWF), Korean Confederation of Trade Unions (KCTU) og International Metalworkers' Federation (IMF), GB.313/INS/9 s. $125-142$.

Det fremgår av CFAs rapport at koreansk høyesterett la vekt på disse forholdene (avsnitt 460). 
fullt ut kan nyte godt av rettigheter relatert til organisasjonsfriheten, inkludert tilgang til kollektive forhandlinger:

«(i) ensure that 'self-employed' workers, such as heavy goods vehicle drivers, fully enjoy freedom of association rights, in particular the right to join the organizations of their own choosing; (ii) to hold consultations to this end with all the parties involved with the aim of finding a mutually acceptable solution so as to ensure that workers who are self-employed could fully enjoy trade union rights under Conventions Nos 87 and 98 for the purpose of furthering and defending their interest, including by the means of collective bargaining; and (iii) in consultation with the social partners concerned, to identify the particularities of self-employed workers that have a bearing on collective bargaining so as to develop specific collective bargaining mechanisms relevant to selfemployed workers, if appropriate» (avsnitt 461, kursivert her).

CFAs resonnement bekrefter for det første at oppdragstakere i utgangspunktet er omfattet av forhandlingsretten. For det andre bygger vurderingen på at slike oppdragstakere som er omfattet, skal ha tilgang til samme type kollektive forhandlingsmekanisme som arbeidstakere. Det er verd å merke seg at CFA ikke kun knyttet vurderingen til den aktuelle gruppen trailersjåfører, men til oppdragstakere mer generelt, jf. «such as». Ettersom saken gjaldt en spesiell gruppe oppdragstakere, kan det likevel tenkes at rettigheten kan avgrenses til visse oppdragstakere. På dette punktet gir praksis etter ESP ytterligere veiledning.

\subsection{Nærmere om retten etter ESP art. 6 nr. 2}

\subsubsection{Utgangspunkter og Sosialpaktkomiteens avgjørelse i ICTU vs. Irland}

ESP art. 6 nr. 2 gir «workers» rett til forhandlinger med sikte på å regulere «terms and conditions of employment by means of collective agreeements». Det innebærer både negative og positive forpliktelser for statene. Nasjonal rett må anerkjenne at «employers' and workers' organisations may regulate their relations by collective agreement». ${ }^{140}$ Det kreves aktive tiltak for å «facilitate and encourage» inngåelsen av kollektive avtaler der det er nødvendig og hensiktsmessig, særlig der spontan utvikling av kollektive forhandlinger ikke anses tilstrekkelig. Selve forhandlingene skal være «free and voluntary». Både forhandlinger og avtaleinngåelse skal altså bygge på frivillighet, på tilsvarende måte som etter EMK art. 11. ${ }^{141}$ Det er derfor ikke tale om en egentlig rett til å inngå bindende kollektive avtaler.

Sosialpaktkomiteen ${ }^{142}$ hadde inntil nylig ikke tatt stilling til om retten etter art. 6 nr. 2 omfatter oppdragstakere. At ordlyden refererer til forhandlinger om vilkår i «employment»,

140 Se til dette avsnittet Digest of the case law of the European Committee of Social Rights, 2018 [ECSR Digest 2018], s. 98, som viser til Conclusions I (1969), Statement on Interpretation of Article $6 \S 2$.

141 Se slik David Harris and John Darcy, The European Social Charter, 2. ed. 2001 [Harris/Darcy 2001] s. 101.

142 Sosialpaktkomiteen er en uavhengig ekspertkomité som avgjør spørsmål om situasjonen i statene er i overensstemmelse («conformity») med Den europeiske sosialpakten (ESP), dels ved den alminnelige behandling av statenes rapporter og dels ved behandlingen av saker etter en kollektiv klageadgang regulert $\mathrm{i}$ ESP art. D og Tilleggsprotokoll til Den europeiske sosialpakt som fastsetter et system for kollektive klager, 1995, i kraft 1. juli 1998. Protokollen ble ratifisert av Norge 30. mars 1997. 
kan tas til inntekt for en snevrere forståelse. Når det gjelder plikten etter ESP art. 6 nr. 1, om å fremme «joint consultation between workers and employers», er den ansett å gjelde «consultation between employees and employer» eller deres organisasjoner. ${ }^{143}$ Når det gjelder ESP art. 6 nr. 2, er både ordlyden og sammenhengen med nr. 1 tatt til inntekt for at oppdragstakere ikke er «workers». Blant annet har Harris og Darcy uttalt at «as its terms indicate, Article 6 (2) does not apply to the self-employed». ${ }^{144}$ I saken ICTU vs. Irland fra 2018 la Sosialpaktkomiteen imidlertid til grunn at ESP art. 6 nr. 2 også omfatter visse oppdragstakere, og la føringer for hvilke avgrensninger som kan være legitime inngrep. ${ }^{145}$ Avgjørelsen er følgelig helt sentral for forhandlingsrettens nærmere rekkevidde etter ESP.

Saken var en kollektiv klage reist mot Irland av den største sammenslutningen av fagforeninger i Irland, Irish Congress of Trade Unions (ICTU). ICTU hevdet at situasjonen i Irland, der visse oppdragstakere var forhindret i å forhandle kollektivt som følge av at de var regnet som foretak etter konkurranserettslige regler, utgjorde en krenkelse av ESP art. 6. Komiteen fant at situasjonen frem til en lovendring i 2017 utgjorde en krenkelse. Ved vurderingen av dagens situasjon, etter lovendringen, delte komiteen seg. Flertallet (11 medlemmer) fant ikke grunnlag for å konstatere krenkelse, mens et mindretall (to medlemmer) konkluderte med at en krenkelse fortsatt forelå.

I det følgende skal jeg drøfte hvilke avklaringer avgjørelsen gir grunnlag for, av forhandlingsrettens rekkevidde i utgangspunktet (punkt 5.3.4) og av inngrepsvurderingen (punkt 5.3.5). Først er det nødvendig å forklare sakens bakgrunn noe nærmere (punkt 5.3.2) og kommentere komiteens konkrete vurdering av situasjonen i Irland (punkt 5.3.3).

\subsubsection{Sakens bakgrunn}

Klagen var utløst av en avgjørelse fra det irske konkurransetilsynet fra 2004. I avgjørelsen var selvstendige skuespillere ansett som foretak og omfattet av forbudet mot konkurransebegrensende samarbeid etter irsk konkurranselov og TFEU art. 101 (1). ${ }^{146}$ I klagen var det påpekt at avgjørelsen hindret kollektive forhandlinger om vederlag og andre arbeidsvilkår for tre bestemte grupper oppdragstakere: visse skuespillere, musikere og journalister.

Tilsynets avgjørelse gjaldt en kollektiv avtale mellom en forening for skuespillere og en arbeidsgiverforening for reklamebyråer om minimumsbetaling og andre arbeidsvilkår for skuespillere som gjør voice-over i reklame. ${ }^{147}$ Tilsynet anså skuespillerne for å være egne foretak og slo fast at avtalen var i strid i forbudet mot konkurransebegrensende samarbeid. Avgjørelsen fikk imidlertid konkrete ringvirkninger for to andre grupper.

\footnotetext{
143 ECSR Digest 2018 s. 98, som viser til Conclusions I (1969), Statement on Interpretation of Article $6 \S 1$. 144 Harris/Darcy 2001 s. 103. Se også Andrzej M. Swiatkowski, Charter of Social Rights of the Council of Europe, 2007 [Swiatkowski 2007] s. 222.

145 ECSR avgjørelse i ICTU v. Irland, klage nr. 123/2016 (avsnitt 35-40).

146 Forbudet er nedfelt i Competition Act, Act no. 14 of 2002, Section 4, som gjennomfører TFEU art. 101.

147 Decision of the Competition Authority 31. August 2004, no. E/04/002.
} 
En forening for journalister hadde rammeavtaler med to arbeidsgiverorganisasjoner om forhandlinger om minimumsbetaling for frilansjournalister. Etter avgjørelsen nektet arbeidsgiverorganisasjonen å forhandle om slike bestemmelser med henvisning til at det ville stride mot konkurranserettslige regler. I tillegg hevdet en fagforening som organiserte både ansatte og selvstendige musikere, at avgjørelsen forhindret dem i å forhandle vederlag på vegne av de medlemmene som var oppdragstakere.

Den irske konkurranseloven ble endret i tiden før klagen ble tatt opp til vurdering. Fra 2017 ble det innført et unntak fra forbudet mot konkurransebegrensende samarbeid. ${ }^{148}$ Forbudet gjelder ikke lenger for kollektive forhandlinger og avtaler for «a relevant category of selfemployed worker». ${ }^{149}$ Det omfatter for det første et «automatisk» unntak for spesifikke grupper angitt i (vedlegg til) loven. Dette er nettopp de tre gruppene som var fremhevet i klagen: (1) skuespillere engasjert som «voice-over actors», (2) musikere engasjert som «sessions musicians», og (3) journalister engasjert som «freelance journalists». ${ }^{150}$ For det andre gjelder regler om unntak ved myndighetsbeslutning. Grupper som av departementet blir angitt som «false self-employed» eller «fully dependent self-employed worker», kan også unntas. ${ }^{151}$ Beslutning om unntak krever søknad fra en fagforening («trade union») som representerer den aktuelle gruppen, og at gruppen enten er «false self-employed» eller «fully dependent self-employed» etter nærmere definisjoner i loven. ${ }^{152}$ I tillegg kreves bevis for at det å unnta gruppen ikke vil ha nevneverdig betydning i det aktuelle markedet eller stå i motsetning til andre konkurranserettslige regler. ${ }^{153}$

Lovendringen gir definisjoner av «false» og «fully dependent self-employed» i Section 15D. En «false selfemployed worker» er et individ som oppfyller seks kumulative krav:

(a) performs for a person ('other person'), under a contract (whether express or implied and if express, whether orally or in writing), the same activity or service as an employee of the other person,

(b) has a relationship of subordination in relation to the other person for the duration of the contractual relationship,

(c) is required to follow the instructions of the other person regarding the time, place and content of his or her work,

(d) does not share in the other person's commercial risk,

(e) has no independence as regards the determination of the time schedule, place and manner of performing the tasks assigned to him or her, and

(f) for the duration of the contractual relationship, forms an integral part of the other person's undertaking;

En «fully dependent self-employed worker» er et individ som oppfyller to kumulative krav:

148 Competition (Amendment) Act, no. 12 of 2017 [Amendment Act], i kraft 7. september 2017.

149 Amendment Act Part 2B, Section 15E og Section 15D.

150 Gruppene er en «relevant category of self-employed worker» jf. Section 15D bokstav a, jf. Schedule 4.

151 Slike grupper er en «relevant category of self-employed worker», jf. Section 15D bokstav b, jf. Section $15 \mathrm{~F}$.

152 Kravet om søknad fremgår av Section 15E og prosedyrekravene av Section 15F, som krever bevis for at gruppen faller innenfor definisjonene av «false self-employed» eller «fully dependent self-employed worker».

De mer spesifikke kravene fremgår av Section 15F (2). 
(a) who performs services for another person (whether or not the person for whom the service is being performed is also an employer of employees) under a contract (whether express or implied, and if express, whether orally or in writing), and,

(b) whose main income in respect of the performance of such services under contract is derived from not more than 2 persons;

Sammenlignet med norsk rett er begge kategorier nokså snevert definert. Ut fra ordlyden synes «false self-employed» bare å treffe rene omgåelsestilfeller, der det i realiteten klart er et underordningsforhold. «Fully dependent self-employed» synes å være en bestemt type $\emptyset$ konomisk avhengig oppdragstakere, slike som har hovedinntekten fra én eller to oppdragsgivere. Unntakene virker derfor bare anvendelige i deler av gråsonen.

\subsubsection{Komiteens konkrete vurdering av situasjonen i Irland}

Komiteen fant enstemmig at situasjonen $f \not \varnothing$ r lovendringen i 2017 utgjorde en krenkelse. Situasjonen ble vurdert slik at det gjaldt et forbud mot kollektive forhandlinger om vederlag for de tre gruppene som var fremhevet i klagen. Forbudet var en direkte konsekvens av at disse var regnet som foretak etter konkurransereglene.

Komiteen tok utgangspunkt $\mathrm{i}$ at oppdragstakere er «workers» med rett til kollektive forhandlinger etter ESP art. $6 \mathrm{nr}$. 2, og at forbudet dermed var et inngrep i retten som krevde hjemmel i art. G (avsnitt 95, jf. 35-40). Forbudet var forankret i lov og fremmet et legitimt mål om effektiv og uhindret konkurranse for å sikre andres rettigheter og friheter. Men inngrepet ble ikke vurdert som nødvendig i et demokratisk samfunn. Forbudet var et for vidtrekkende inngrep fordi foretaksbegrepet var «over-inclusive» (avsnitt 98). Krenkelsen skyldtes følgelig forbudets personelle rekkevidde, det omfattet flere oppdragstakere enn ESP tillater. Begrunnelsen var at de tre gruppene oppdragstakere ikke var genuint selvstendige oppdragstakere, særlig fordi de åpenbart ikke ville ha innflytelse på betalingsvilkårene uten en rett til kollektive forhandlinger (avsnitt 99).

Forholdet til konkurranserettslige hensyn ble ikke ansett problematisk. Komiteen mente at kollektive forhandlinger og avtaler for slike grupper oppdragstakere ikke ville påvirke konkurransen nevneverdig annerledes («significally different») enn om de gjaldt arbeidstakere (avsnitt 100).

Komiteen delte seg i vurderingen av situasjonen etter lovendringen i 2017. De tre nevnte gruppene hadde da fått adgang til kollektive forhandlinger ved det automatiske unntaket. For deres del var situasjonen følgelig brakt i overensstemmelse med art. 6 nr. 2. Andre oppdragstakere var avhengige av unntak ved myndighetsbeslutning etter søknad, som forutsatte at de var «false» eller «fully dependent self-employed». ICTU hadde imidlertid ikke ført bevis for at bestemte grupper var blitt forhindret fra å forhandle kollektivt fordi de falt utenfor disse kategoriene. Det ble avgjørende for komiteens flertall. Disse medlemmene poengterte at påstanden om at hvorvidt kategoriene og prosedyren for unntak ga en for snever rekkevidde, dermed var «essentially speculative» (avsnitt 110). De viste til at forbudet mot 
kollektive forhandlinger for oppdragstakere før lovendringen ikke var forankret i lovens ordlyd, men i konkurransemyndighetenes tolkning. Spørsmålet om kategoriene var for snevre og om søknadsprosedyren var for streng, måtte da, på lignende måte, bero på tolkningen av kravene i praksis. I fravær av slik praksis fant flertallet ikke bevismessig grunnlag for å konstatere at rammene i art. G var overtrådt. Flertallet understreket imidlertid særskilt at irske myndigheters praktisering av adgangen til unntak ved søknad må være i tråd med den forståelsen av ESP art. 6 nr. 2 og art. G som komiteen la til grunn (avsnitt 111). Det var derfor fraværet av praksis, ikke en nærmere vurdering av kategoriene, som ledet til at ingen krenkelse forelå. Flertallets vurdering gir med andre ord ingen aksept for at kollektive forhandlinger kan avgrenses til de snevre kategoriene i den irske lovgivningen.

Mindretallet mente derimot at regelverket som sådant utgjorde en krenkelse. ${ }^{154}$ Disse medlemmene pekte på at forbudet mot konkurransebegrensende samarbeid er generelt utformet. Å gjøre adgangen til forhandlinger betinget av en skjønnsmessig beslutning fra den utøvende makt var et alvorlig hinder - «a serious barrier» - som kan resultere $i$ at oppdragstakere avstår fra kollektivt engasjement. Det var i seg selv en for vidtrekkende og illegitim begrensning, i strid med statenes uttrykkelige forpliktelse til å fremme («promote») kollektive forhandlinger. For mindretallet var det derfor unødvendig å ta stilling til kategoriene fordi selve ordningen med unntak ved skjønnsmessig myndighetsbeslutning var en krenkelse.

Dissensen skyldtes etter dette ulikt syn på hvor konkret en krenkelse må komme til uttrykk, ikke ulikt syn på rettens rekkevidde og innhold. Mens flertallet var pragmatisk og ville avvente hvordan regelverket slår ut i praksis, var mindretallet prinsipiell og tok stilling til regelverket slik det er. Avgjørelsen viser uansett klart at komiteen står samlet om den materielle forståelsen av retten til kollektive forhandlinger. ${ }^{155}$

\subsubsection{Utgangspunktene og rammene for inngrepsvurderingen}

En første avklaring gjelder hvem retten $i$ utgangspunktet omfatter. Avgjørelsen bygger på at oppdragstakere er «workers» med rett til kollektive forhandlinger etter ESP art. 6 nr. 2. Det fremgår av komiteens resonnement og er en utvidelse sammenlignet med tradisjonell forståelse. ${ }^{156}$ Komiteen viste til praksis etter andre bestemmelser om arbeidsforhold i ESP. Konvensjonens ordlyd sier nokså gjennomgående ingenting om hvorvidt oppdragstakere er omfattet. ${ }^{157}$ I praksis er det da lagt til grunn at oppdragstakere er omfattet, med mindre det fremgår av konteksten at rettigheten er begrenset til «employed persons», altså

154 Joint dissenting opinion of Petros Stangos og Barbara Kresal.

155

156

157 Det eneste unntaket er ESP art. 19 om rettigheter for «migrant workers and their families», der det heter i nr. 10 at statene skal «extend the protection and assistance provided for in this article to self-employed migrants insofar as such measures apply». 
arbeidsavtaleforhold. ${ }^{158}$ Komiteen pekte på dette og konstaterte at konteksten for retten til kollektive forhandlinger ikke tilsier en slik generell begrensning (avsnitt 35). Tross referansen til «employment» mente komiteen at ordlyden ikke kunne begrunne inngrep for bestemte grupper av «workers». Komiteen la til grunn at enhver begrensning i relasjon til oppdragstakere krever derfor hjemmel i art. G: «Therefore, any restrictions are exclusively limited to those provide[d] for by Article G» (avsnitt 36, kursivert her). Praksis etter ILO 98 ble også trukket inn (avsnitt 39).

Understrekningen av at enhver begrensning skal vurderes som et inngrep etter art. G, er betydningsfull. Det impliserer at man ikke som et utgangspunkt kan avgrense «workers» mot visse oppdragstakere. Begrensninger overfor alle oppdragstakere - også de klart selvstendige - må forankres i art. G. Dette bekreftes av det vurderingstemaet for inngrep som komiteen stilte opp. Vurderingstemaet gir nettopp en mekanisme for å avgrense mot oppdragstakere som er genuint selvstendige, se straks nedenfor.

Dermed avklarer avgjørelsen på den annen side at avgrensning av retten til visse grupper av oppdragstakere kan være tillatelige inngrep etter art. G. To andre avklaringer gjelder rammene for denne inngrepsvurderingen.

For det første er det lagt til grunn at inngrep begrunnet i konkurranserettslige regler kan ligge innenfor rammen av art. G. Slike regler har forankring i lov og kan forfølge legitime interesser ved å beskytte andres rettigheter og friheter. Komiteen ordla seg riktignok nokså forsiktig. Den tok det motsatte utgangspunktet og poengterte at man ikke automatisk kan legge til grunn at inngrep begrunner i konkurranserettslige regler ikke er legitime:
«In this respect, it cannot be automatically presumed that restrictions following from competition law or commercial law do not pursue a legitimate aim and/or are not necessary in a democratic society, for example to protect the rights and freedoms of others» (avsnitt 36).

Komiteens konkrete vurdering viser videre at den har sett hen til påvirkningen på konkurransen. Som nevnt ovenfor påpekte komiteen at kollektive forhandlinger og avtaler for de oppdragstakerne klagen gjaldt, ikke ville påvirke konkurransen på særlig annen måte enn om de gjaldt arbeidstakere (avsnitt 100). Samtidig understreket komiteen sin prinsipielle holdning til forholdet mellom ESP og EU-retten: At nasjonale regler bygger på bindende EUrett, innebærer ikke at reglene faller utenfor ESPs virkeområde (avsnitt 113).

Avgjørelsen trekker for det andre en ytre ramme for hvilke inngrep som kan være tillatelige. Komiteen sa klart at et forbud - «an outright ban» - mot kollektive forhandlinger for alle oppdragstakere vil være for vidtrekkende («excessive») og i strid med formålet med retten til kollektive forhandlinger (avsnitt 40).

Innenfor disse rammene er det vurderingstemaet og terskelen for inngrep som avgjør hvilke begrensninger i rekkevidden som er tillatelige.

158 For eksempel er oppdragstakere omfattet av retten til arbeid (ESP art. 1), se Hotvedt 2016 s. 251-253 med videre referanser. 


\subsubsection{Vurderingstemaet og terskelen for inngrep}

Avgjørelsen viser at komiteen gjennom inngrepsvurderingen søker å avstemme hensynene bak kollektive forhandlingsmekanismer mot hensynene bak konkurranserettslige regler, i lys av de faktiske forholdene på arbeidsmarkedet.

Komiteen tok utgangpunkt $\mathrm{i}$ at lav betaling og manglende $\varnothing$ konomisk selvstendighet for oppdragstakere er et voksende problem. Fremvekst av kontraktsformer utformet for ikke å være arbeidsavtaler, og derved unngå arbeidsrettslige regler, ble ansett å lede til at et økende antall «workers» faller utenfor definisjonen av en avhengig arbeidstaker. Denne utviklingen måtte tas i betraktning - «must be taken into account» - ved fastleggelsen av den nærmere rekkevidden av retten til kollektive forhandlinger for oppdragstakere (avsnitt 37).

Komiteen fremhevet at kollektive forhandlingsmekanismer er begrunnet i den svakere forhandlingsposisjonen for de som besitter arbeidskraften ved fastsettelse av arbeidsvilkårene. Det står i kontrast til konkurranseretten, som bygger på at koordinering av tilbyderes interesser truer rettferdige priser for konsumenter. Komiteen mente EU-domstolen gjennom tariffunntaket har akseptert behovet for å overkomme manglende individuell forhandlingsstyrke $\mathrm{i}$ «labour contracts». ${ }^{159}$

På denne bakgrunn avviste komiteen at distinksjoner mellom «worker» og «self-employed» er tilstrekkelig for å avgjøre forhandlingsrettens nærmere rekkevidde. Det avgjørende måtte i stedet være maktubalanse mellom besittere av arbeidskraft og dem som etterspør arbeidskraften:

«In establishing the type of collective bargaining that is protected by the Charter, it is not sufficient to rely on distinctions between worker and self-employed, the decisive criterion is rather whether there is an imbalance of power between the providers and engagers of labour. Where providers of labour have no substantial influence on the content of contractual conditions, they must be given the possibility of improving the power imbalance through collective bargaining» (avsnitt 38, kursivert her).

Uttalelsen viser at det sentrale er ubalanse i mulighet til å påvirke arbeidsvilkårene. Oppdragstakere uten vesentlig innflytelse på arbeidsvilkårene dersom de skulle forhandle individuelt - «no substantial influence» - må få mulighet til å forbedre maktubalansen gjennom kollektive forhandlinger. Dette er et grunnleggende poeng i avgjørelsen. Det er gjentatt senere av både flertall og mindretall. ${ }^{160}$

Med dette oppstiller komiteen etter mitt syn generelle retningslinjer for inngrep i retten til kollektive forhandlinger. Vurderingstemaet er skjevhet i forhandlingsposisjonene og

159 ECSR viste til Albany, og beskrev unntaket og begrunnelsen slik: «To overcome the lack of individual bargaining power the anti-cartel regulations are considered inapplicable to labour contracts», se ICTU vs. Irland (avsnitt 38, kursivert her).

160 Ved vurderingen av den irske situasjonen etter lovendringen fremheves dette av flertallet (avsnitt 111), se sitatet ovenfor i punkt 5.3.3. Også mindretallet slutter seg uttrykkelig til avsnitt 38, se Joint dissenting opinion of Petros Stangos og Barbara Kresal (s. 31, andre avsnitt). 
mangelfull individuell forhandlingsstyrke. Inngrep i rekkevidden begrunnet $\mathrm{i}$ konkurranserettslige regler er utillatelig overfor oppdragstakere som ikke har vesentlig innflytelse på arbeidsvilkårene på individuelt nivå. Det indikerer at terskelen for tillatelige inngrep ligger relativt høyt.

Vurderingen av den irske situasjonen før lovendringen gir ytterligere veiledning. Som forklart i punkt 5.3.3 var det en krenkelse å forby kollektive forhandlinger for de tre gruppene oppdragstakere (voice-over skuespillere, frilansjournalister og visse musikere). Dette var ikke begrunnet med at deres «selvstendige» status representerte en omgåelse og i realiteten var et underordningsforhold. Tvert imot, komiteen uttalte at det var unødvendig å ta stilling til om de var «false» eller «fully dependent self-employed», og fortsatte:
«..., the Committee considers it evident that they cannot predominantly be characterized as genuine independent self-employed meeting all or most of criteria such as having several clients, having the authority to hire staff, and having the authority to make important strategic decisions about how to run the business. The self-employed workers concerned here are obviously not in a position to influence their conditions of pay once they have been denied the right to bargain collectively» (avsnitt 99, kursivert her).

Dette tilsier at inngrep bare kan gjøres overfor oppdragstakere som hovedsakelig kan karakteriseres som genuint selvstendige. Å være genuint selvstendig er forklart som at alle eller de fleste typiske kjennetegn ved selvstendig virksomhet er tilstede. Å ha flere kunder og myndighet til å ansette og treffe strategiske beslutninger er trukket frem $i$ tillegg til det å ha innflytelse på arbeidsvilkårene på individuelt nivå. Det styrker inntrykket av at terskelen for inngrep ligger høyt.

For oppdragstakere i gråsonen vil det nokså gjennomgående være vanskelig å tilfredsstille kravene. Avgjørelsen i ICTU vs. Irland etterlater derfor et inntrykk av det normalt ikke kan gjøres inngrep som utelukker slike oppdragstakere fra retten til kollektive forhandlinger.

\subsection{Rett til forhandlinger om tariffavtale for oppdragstakere i gråsonen?}

At oppdragstakere nå anses som «workers» som i utgangspunktet er omfattet av retten til kollektive forhandlinger etter både ILO 98 og ESP art. 6 nr. 2 er i seg selv en viktig avklaring. Et viktig begrepsmessig poeng er at «employer» (arbeidsgiver) i disse instrumentene ikke er uløselig knyttet til arbeidsavtalerelasjonen eller kun er en speilvending av arbeidstakerbegrepet. «Arbeidsgiver» kan betegne den ene part i andre relasjoner, her relasjonen til oppdragstakere. Begrepsforståelsen viser at de norske oversettelsene av ILO 98 og ESP er problematiske. Når kollektive forhandlinger er formulert som en rett for henholdsvis «arbeidere» og «arbeidstakere», gir det misvisende signaler om rekkevidden. ${ }^{161}$

ICTU mot Irland gir viktige avklaringer om rettens rekkevidde etter ESP art. 6 nr. 2. Konkurranserettslige regler kan ikke begrunne et forbud mot kollektive forhandlinger for alle

161 Se oversettelsene i UDs traktatregister, som er tilgjengelige i Lovdata, se https://lovdata.no/register/traktater. 
oppdragstakere. Bare de genuint selvstendige kan utelukkes, og terskelen synes å være høy. Oppdragstakere i gråsonen skal derfor normalt ha adgang til kollektive forhandlinger.

EMDs tolkningsmetode gjør disse avklaringene høyst relevante for EMK art. 11. Forståelsen av ILO 98 og ESP - blant annet ICTU vs. Irland - har dermed «dobbel» betydning i norsk rett. Forståelsen påvirker tolkingen av norsk rett direkte gjennom presumsjonsprinsippet og indirekte via tolkningen av EMK art. 11. ${ }^{162}$ Det forankrer avklaringene ikke bare i menneskerettslovens forrangsbestemmelse, men også i Grunnloven $\S 101$. Høyesterettspraksis gir for øvrig flere eksempler på at ILO 98 og ESP med tilhørende praksis trekkes inn i saker som berører organisasjonsfrihetens innhold etter norsk rett. ${ }^{163}$

Hva det nærmere innholdet i retten til kollektive forhandlinger er for de oppdragstakerne som er omfattet, er ikke like avklart, tross enkelte signaler fra CFA. Spørsmålet er om forpliktelsen til å tillate og fremme forhandlinger om arbeidsvilkår ved «collective agreement» betyr at slike oppdragstakere skal ha adgang til å forhandle tariffavtaler, eller om tilgang til andre typer kollektive forhandlinger kan være tilstrekkelig. Det avhenger både av rettens innhold i utgangspunktet og hvor langt inngrepsadgangen går.

Rettens innhold rommer et visst element av skjønn. Statenes forpliktelse til å fremme forhandlinger etter ESP art. 6 nr. 2 er knyttet til hva som er «necessary and appropriate». Det er ment å gi statene et visst skjønn der det eksisterer andre tilfredsstillende mekanismer. ${ }^{164}$ Men det synes først og fremst å være en åpning for å lovregulere arbeidsvilkår som det $\mathrm{i}$ utgangspunktet skal kunne forhandles om. Harris og Darcy trekker frem som eksempel at lovregulert lønnsfastsettelse kan tillates fremfor lønnsforhandlinger. ${ }^{165}$ For visse offentlige tjenestemenn er det akseptert at ordinære prosedyrer for kollektive forhandlinger ikke får anvendelse. Det har nettopp sammenheng med at deres arbeidsvilkår i større grad enn andres er underlagt lovregulering. ${ }^{166}$

ICTU mot Irland gir ikke direkte veiledning. Komiteen avsto fra å definere hvordan oppdragstakere er omfattet: «The Committee does not consider it appropriate to elaborate a general definition of how self-employed workers are covered by Article 6§2» (avsnitt 40, kursivert her). Vurderingene av inngrepsadgangen er konsentrert om personell rekkevidde og behandler ikke rettens innhold. Det kom heller ikke på spissen i saken ettersom situasjonen i

162 Poenget om påvirkning via EMK er tidligere fremhevet blant annet av Stein Evju, «Boikott, EØS-rett og Grunnlov - 'Holship', HR-2016-2554-P», Nytt i privatretten, nr. 12017 s. 1-3, på s. 3, se også nærmere Stein Evju, «Norway : Supreme Court HR-2016-2554-P», 37 International Labour Law Reports (2018) s. 3-30, og av Marianne Jenum Hotvedt, «Tariffavtaler, rettsutvikling og organisasjonsfrihet», Lov og Rett, 2017 s. 86-109, på s. 90-91, https://doi.org/10.18261/issn.1504-3061-2017-02-03.

Se særlig Rt. 2001 s. 248, Rt. 2001 s. 1413 og Rt. 2008 s. 1601. I sistnevnte avgjørelse ble ESP med tilhørende praksis trukket inn sammen med EMK art. 11 i drøftelsen av organisasjonsfriheten som «et alminnelig ulovfestet norsk rettsprinsipp» (se særlig avsnitt 37-53).

Harris/Darcy 2001 s. 101. Også etter EMK art. 11 er det i utgangspunktet antatt å være en vid skjønnsmargin i hvordan fagforeningers frihet skal vernes, se Harris/O’Boyle/Warbrick 2018 s. 723. 
Irland før lovendringen ble ansett å utgjøre et forbud mot kollektive forhandlinger for de nevnte gruppene. Det var åpenbart et inngrep i rettens innhold.

Komiteens begrunnelse gir likevel støtte for adgang til samme type forhandlinger som arbeidstakere. Sentrale premisser var at konteksten for retten til kollektive forhandlinger ikke tilsier generelle begrensninger for oppdragstakere sammenlignet med arbeidstakere, og at enhver begrensning utgjør et inngrep og krever hjemmel i art. G. Vurderingen av inngrepsadgangen bygget på at visse oppdragstakere må sidestilles med arbeidstakere for å ivareta de hensynene som begrunner kollektive forhandlingsmekanismer, og forholdet til konkurranserettslige hensyn ble betraktet på samme måte som for arbeidstakere. Denne argumentasjonen hviler på en logikk om at oppdragstakere som ikke er genuint selvstendige, skal ha tilgang til samme type forhandlingsmekanismer som arbeidstakere. I norsk kontekst vil det tilsi en adgang til å forhandle tariffavtaler.

Det er ikke klarlagt om menneskerettsbeskyttelsen av retten til kollektive forhandlinger for oppdragstakere i gråsonen krever adgang til forhandle tariffavtaler i norsk sammenheng. Men slik beskyttelsen er begrunnet, gir det etter mitt syn vektige argumenter for en slik adgang.

\section{Arbeidstvistloven og tolkningsmulighetene}

Adgangen til å forhandle tariffavtaler i norsk rett er ikke skarpt avgrenset. Oppdragstakere i gråsonen kan prinsipielt sett være arbeidstakere i arbeidstvistlovgivningens forstand. Arbeidstvistlovens grense mellom arbeidstakere og oppdragstakere er fleksibel og kan blant annet påvirkes av hvem tariffpartene mener de $b \phi r$ kunne avtale tariffregulering for. Muligheten for å inkludere regulering av oppdragstakerforhold i det som ellers er en tariffavtale, reiser en rekke vanskelige spørsmål om rettsvirkningene. Samtidig er det uttalelser i rettspraksis som kan antyde en viss frihet for partene til forhandle om tariffregulering for oppdragstakere.

Artikkelen har vist at internasjonale regler i større grad enn tidligere åpner for - og taler for - en adgang til å forhandle tariffavtaler for visse oppdragstakere.

Drøftelsen av konkurranserettslige skranker har klarlagt at tariffunntaket i hvert fall omfatter visse oppdragstakere, og at dets nærmere rekkevidde er noe usikker. Samtidig er det visse holdepunkter for at unntaket i første rekke skal avgrenses mot genuint selvstendige oppdragstakere. Konkurranserettslige regler behøver derfor ikke være til hinder for en adgang i norsk rett til å forhandle tariffavtaler der det er tvil om arbeidstakerstatus.

Drøftelsen av menneskerettslige krav har på den annen side klart vist at oppdragstakere har rett til kollektive forhandlinger, og at inngrepsadgangen bare åpner for å utelukke de genuint selvstendige. Det er tvil om hva rettighetens nærmere innhold er for oppdragstakeres del. Men begrunnelsen for å omfatte visse oppdragstakere bygger på at de må sidestilles med arbeidstakere både når det gjelder behovet for kollektive forhandlinger og forholdet til 
konkurranserettslige hensyn. Denne begrunnelsen tilsier at oppdragstakere i gråsonen bør ha adgang til å forhandle tariffavtaler og ikke være henvist til andre former for kollektive avtaler.

En slik adgang vil bidra til å forenkle flere av de avgrensningsproblemene arbeidstvistloven reiser. Regulering på gruppenivå der den arbeidsrettslige statusen er uklar, vil realistisk sett omfatte i hvert fall enkelte personer som kan regnes som arbeidstakere i lovens forstand etter en helt ordinær og individuell vurdering, og slik sett være en tariffavtale i lovens forstand. $\AA$ regne reguleringen for hele gruppen som tariffregulering av arbeidstakerforhold der partene legger opp til det, vil gjøre det enklere å fastlegge rettsvirkningene.

Adgang til å forhandle tariffavtaler for arbeidsforhold i gråsonen synes å kreve en utvidende tolkning av arbeidstvistlovens arbeidstakerbegrep. Men kanskje krever det først og fremst et skifte i perspektiv. Fremfor å fokusere på om kjennetegn ved arbeidstakerforhold er tilstede, slik momentlisten legger opp til, kan man spørre om oppdragstakeren er klart og genuint selvstendig og derfor må holdes utenfor rammeverket for tariffavtaler. I den sammenheng kan den nye danske ferieloven være til inspirasjon. ${ }^{167}$ Etter forarbeidene skal det være avgjørende om det er «grundlag for at statuere selvstændighed i udførelsen af arbejde for en anden», slik at personen «er reelt selvstændig». ${ }^{168}$ Løsningen bygger på en vurdering av «atypiske beskæftigelsesforhold» som «freelancere, konsulenter, honorarlønnede» $\mathrm{i}$ et moderne arbeidsmarked opp mot lovens beskyttelsesformål. ${ }^{169}$ En lignende tilnærming er å presumere arbeidstakerforhold og kreve bestemte - eventuelt også klare - holdepunkter for å konstatere oppdragsforhold. Den tidligere nevnte «ABC-testen» $\mathrm{i}$ californisk rett er bygget over en slik lest. ${ }^{170}$

En tolkning der arbeidsforhold i gråsonen omfattes av arbeidstakerbegrepet, er i tråd med arbeidstvistlovens formål om å utjevne også sosioøkonomiske maktskjevheter. Lovgiver har valgt å holde arbeidstakerbegrepet fleksibelt blant annet for at det skal kunne tilpasses nye tilknytningsformer og reflektere utviklingen på arbeidsmarkedet. Å la arbeidsmarkedets parter forhandle om tariffregulering for slike arbeidsforhold er nettopp en måte å la begrepet reflektere utviklingen. Dessuten kan det effektivisere retten til forhandlinger i omgåelsestilfeller, der realitetene viser seg å være tydelige underordningsforhold.

Selv med en utvidende tolkning må det trekkes en grense. Menneskerettsbeskyttelsen gir veiledning for hvor grensen bør gå. Å være genuint selvstendig krever både selvstendighet under utførelsen av arbeidet og en viss individuell forhandlingsstyrke. Mens der det er visse

167 Lov nr. 60 af 30/01/2019, i kraft 1. september 2020 (med unntak av lovens $\S$ 49, som trådte i kraft 1. januar 2019).

Ny ferielov og overgang til samtidighedsferie. Betankning afgivet af Beskjaftigelsesministeriets Ferielovsudvalg, Betænkning nr. 15682017 s. 104. Beskjæftigelsesministeriet sluttet seg til vurderingen, se lovforslag 6. desember 2017, 2017/1 LSF 11, s. 23.

Ibid.

170 Se note 53. Forslag om en slik tilnærming er også fremmet i Keith Ewing, John Hendy og Carolyn Jones (ed.) A Manifesto for Labour Law: towards a comprehensive revision of workers' rights, The Institute for Employment Rights (IER) 2016, s. 36. 
likhetstrekk med arbeidstakerforhold eller tydelig preg av sosioøkonomisk ubalanse, bør det være adgang til kollektive forhandlinger om bindende regulering av arbeidsvilkårene. Det foreligger allerede forslag til konkretisering av en slik grensedragning, som søker å ivareta konkurranserettslige hensyn. ${ }^{171}$

En «key finding» i OECDs analyse av behovene i fremtidens arbeidsliv kan treffe godt som en avslutning:

«However, a significant number of workers may still fall in a 'grey zone' between the usual definitions of employee and self-employed, where genuine ambiguity exists about their employment status. For those workers, who share vulnerabilities with employees and salaries employees, and for some self-employed workers in unbalanced power relationships, adapting existing regulation to extend collective bargaining rights may be necessary.» 172

171 Ioannis Lianos, Nicola Countouris og Valerio De Stefano, «Rethinking the competition law/labour law interaction: Promoting a fairer labour market», European Labour Law Journal, Vol. 10 (2019) s. 291-333, https://doi.org/10.2139/ssrn.3465996.

OECD Employment Outlook 2019 s. 190. 